\title{
Dopamine docking studies of biologically active metabolites from Curcuma longa L.
}

\author{
Estudos de docagem molecular de dopamina de metabólitos biologicamente ativos de Curcuma
}

longa $\mathbf{L}$.

Estudios de acoplamiento de dopamina de metabolitos biológicamente activos de Curcuma longa L.

Danilo Magnani Bernardi

ORCID: https://orcid.org/0000-0002-4988-8528 Paranaense University, Brazil

E-mail: neuroumuarama@gmail.com

Juliana Pelissari Marchi

ORCID: https://orcid.org/0000-0002-7779-0253

Paranaense University, Brazil

E-mail: ju-estetica@prof.unipar.br

Cintia de Souza Alferes Araújo

ORCID: https://orcid.org/0000-0001-6028-2589

Paranaense University, Brazil

E-mail: csalferesaraujo@gmail.com

Vanessa Rodrigues do Nascimento ORCID: https://orcid.org/0000-0002-0579-7501

Paranaense University, Brazil

E-mail: vanessanascimento@prof.unipar.br

Diego de Souza Lima

ORCID: https://orcid.org/0000-0002-0660-2390

Universidade Estadual de Maringá, Brazil

E-mail: diegodslima92@gmail.com

Samantha Wietzikoski

ORCID: https://orcid.org/0000-0003-4611-6642

Paranaense University, Brazil

E-mail: swietzikoski@ prof.unipar.br

Marcelo Machado Ferro

ORCID: https://orcid.org/0000-0003-2939-072X

State University of Ponta Grossa, Brazil

E-mail: marmferro@hotmail.com

Edmar Miyoshi

ORCID: https://orcid.org/0000-0001-6159-0532

State University of Ponta Grossa, Brazil E-mail: edmar@uepg.br

Francislaine Aparecida dos Reis Lívero

ORCID: https://orcid.org/0000-0001-6533-0850 Paranaense University, Brazil

E-mail: francislaine@ prof.unipar.br

Flavio Augusto Vicente Seixas

ORCID: https://orcid.org/0000-0002-0117-6919 Paranaense University, Brazil E-mail: favseixas@uem.br

Evellyn Claudia Wietzikoski Lovato ORCID: https://orcid.org/0000-0002-8511-0086 Paranaense University, Brazil E-mail: evellyn@prof.unipar.br

\begin{abstract}
The dopaminergic system is involved in a wide range of neuropsychiatric and neurodegenerative disorders. The lack of receptor subtype specificity is related to several pharmacological side effects that are observed during therapy among parkinsonian and schizophrenic patients. It is of paramount importance to search for new compounds that act on dopamine receptors with therapeutic potential, higher clinical effectiveness, and fewer adverse effects. In the present study, we performed a molecular docking study of $\mathrm{D}_{2}, \mathrm{D}_{3}$, and $\mathrm{D}_{4}$ receptor interactions with 92 metabolites from Curcuma longa using an in silico approach. We sought to identify compounds for possible drug development. A virtual library of compounds was built using molecules that were identified in the phytochemical characterization of C. longa. Protocols that were validated by redocking were applied to a virtual scan of this library using the Autodock-
\end{abstract}


v4.2.3, Autodock Vina, and Molegro-v6.0 Virtual Docker programs, with four repetitions each. The three-dimensional structures of $\mathrm{D}_{2}, \mathrm{D}_{3}$, and $\mathrm{D}_{4}$ receptors in complex with risperidone, eticlopride, and nemonapride were obtained from the Protein Data Bank. Four compounds-stigmasterol, $\beta$-sitosterol, cholest-5-en-3-one, and cholestan-3-ol,2methylene- $(3 \beta, 5 \alpha)$-were the most likely to bind $\mathrm{D}_{2}, \mathrm{D}_{3}$, and $\mathrm{D}_{4}$ dopamine receptors, suggesting their potential for possible drug development.

Keywords: Stigmasterol; $\beta$-sitosterol; Cholest-5-en-3-one; Cholestan-3-ol,2-methylene- (3 $\beta, \quad 5 \alpha)$; Dopamine receptors; Curcuma longa.

\section{Resumo}

O sistema dopaminérgico está envolvido em uma ampla gama de doenças neuropsiquiátricas e neurodegenerativas. A falta de especificidade do subtipo de receptor está relacionada a vários efeitos colaterais farmacológicos que são observados durante a terapia entre pacientes parkinsonianos e esquizofrênicos. É de suma importância a busca por novos compostos que atuem nos receptores da dopamina com potencial terapêutico, maior eficácia clínica e menor número de efeitos adversos. No presente estudo, realizamos um estudo de docagem molecular das interações dos receptores D2, D3 e D4 com 92 metabólitos da Curcuma longa usando uma abordagem in silico. Procuramos identificar compostos para possível desenvolvimento de drogas. Uma biblioteca virtual de compostos foi construída a partir de moléculas que foram identificadas na caracterização fitoquímica de $C$. longa. Os protocolos que foram validados por redocagem e foram aplicados a uma varredura virtual dessa biblioteca usando os programas Autodockv4.2.3, Autodock Vina e Molegro-v6.0 Virtual Docker, com quatro repetições cada. As estruturas tridimensionais dos receptores D2, D3 e D4 em complexo com risperidona, eticloprida e nemonaprida foram obtidas no Protein Data Bank. Quatro compostos - estigmasterol, $\beta$-sitosterol, colest-5-en-3-ona e colestan-3-ol, 2-metileno- $(3 \beta, 5 \alpha)$ - foram os mais propensos a se ligar aos receptores de dopamina D2, D3 e D4, sugerindo seu potencial para possível desenvolvimento de drogas.

Palavras-chave: Estigmasterol; $\beta$-sitosterol; Colest-5-en-3-ona; Colestan-3-ol, 2-metileno- $(3 \beta, 5 \alpha)$; Receptores de dopamina, Curcuma longa.

\section{Resumen}

El sistema dopaminérgico está involucrado en una amplia gama de trastornos neuropsiquiátricos y neurodegenerativos. La falta de especificidad del subtipo de receptor está relacionada con varios efectos secundarios farmacológicos que se observan durante la terapia entre pacientes parkinsonianos y esquizofrénicos. Es de suma importancia buscar nuevos compuestos que actúen sobre los receptores de dopamina con potencial terapéutico, mayor efectividad clínica y menos efectos adversos. En el presente estudio, realizamos un estudio de acoplamiento molecular de las interacciones de los receptores D2, D3 y D4 con 92 metabolitos de Curcuma longa utilizando un enfoque in silico. Buscamos identificar compuestos para el posible desarrollo de fármacos. Se construyó una biblioteca virtual de compuestos utilizando moléculas que se identificaron en la caracterización fitoquímica de C. longa. Los protocolos que fueron validados por redocking se aplicaron a un escaneo virtual de esta biblioteca usando los programas Autodock-v4.2.3, Autodock Vina y Molegro-v6.0 Virtual Docker, con cuatro repeticiones cada uno. Las estructuras tridimensionales de los receptores D2, D3 y D4 en complejo con risperidona, eticloprida y nemonaprida se obtuvieron del Protein Data Bank. Cuatro compuestos (estigmasterol, $\beta$-sitosterol, colest-5-en-3-ona y colestán-3-ol, 2-metilen$(3 \beta, 5 \alpha)$ ) fueron los más propensos a unirse a los receptores de dopamina D2, D3 y D4, lo que sugiere su potencial para el posible desarrollo de fármacos.

Palabras clave: Estigmasterol; $\beta$-sitosterol; Colest-5-en-3-ona; Colestán-3-ol, 2-metilen- (3 $\beta, 5 \alpha)$; Receptores de dopamina; Curcuma longa.

\section{Introduction}

Dopamine (3-hydroxytyramine) modulates several physiological functions, including reward, cognition, emotion, motor control, and blood depuration by the kidneys (Miyoshi et al., 2002; Da Cunha et al., 2009a; Da Cunha et al., 2009b; Wietzikoski et al., 2012; Fontoura et al., 2017; Alfio et al., 2020; Fernandes et al., 2020; Gildea et al., 2019). The dopaminergic system is involved in a wide range of psychiatric disorders (e.g., schizophrenia, depression, bipolar disorder, attention-deficit/hyperactivity disorder, anorexia nervosa, Tourette's syndrome, addiction, and autism), neurological disorders (e.g., Parkinson's disease [PD], Alzheimer's disease, dyskinesia, and dementia with Lewy bodies), and cardiovascular diseases (e.g., hypertension; Badgaiyan, 2016; Broft et al., 2015; Dong et al., 2020; Galaj et al., 2020; Horga et al., 2016; Li et al., 2020; Martel and McArthur, 2020; Martinez et al., 2020; Nakamura et al., 2010; Steeves et al., 2010; Wooten et al., 2015; Yatham et al., 2002, Zhai et al., 2019).

Brain dopaminergic neurons are mainly located in the mesencephalon (i.e., substantia nigra and ventral tegmental 
area) and project throughout four main pathways: nigrostriatal, mesocortical, mesolimbic, and tuberoinfundibular (Alfio et al., 2020; Conn et al., 2020; Hou et al., 2014). After being released into the synaptic cleft, dopamine binds to dopamine receptors. All dopamine receptors are seven-transmembrane domain metabotropic receptors that are divided into two main families, $\mathrm{D}_{1}$ like receptors $\left(D_{1}\right.$ and $\left.D_{5}\right)$ and $D 2$-like receptors $\left(D_{2}, D_{3}\right.$, and $\left.D_{4}\right)$, that couple to $G_{s}$ and $G_{i}$ proteins, respectively (Dong et al., 2020; Martinez et al., 2020). Substances that can interact with dopaminergic receptors have promising therapeutic potential, either by acting as receptor agonists (e.g., pramipexol) or antagonists (e.g., haloperidol).

Dopamine receptor agonists can be used for the symptomatic treatment of patients with early PD and restless leg syndrome (Grimes et al., 2019; Liu et al., 2016). Parkinson's disease is a neurodegenerative disorder that is characterized by the progressive loss of dopaminergic neurons in the substantia nigra (Fontoura et al., 2017; Li et al., 2020; Zhai et al., 2019). Dopamine replacement therapy can mainly alleviate motor symptoms of the disease. However, levodopa (L-DOPA) and dopamine receptor agonists can cause diverse side effects, such as dyskinesias, motor fluctuations, sleepiness, and hallucination (Kim et al., 2015; Paus et al., 2003; Yun et al., 2017).

Dopamine receptor antagonists are widely used antipsychotic medications that are used for the treatment of schizophrenia, bipolar disorder, and other psychotic conditions (Moncrieff et al., 2020). However, antipsychotics are associated with various side effects, such as sedation, weight gain, metabolic disturbances, sexual dysfunction, gastrointestinal distress, and extrapyramidal movement disturbances (Hynes et al., 2020).

It is of paramount importance to search for new compounds that act on dopamine receptors with therapeutic potential, higher clinical effectiveness, and fewer adverse effects. The drug discovery process is particularly challenging because it is both time- and resource-consuming. However, the recent use of newer technologies and information management has led to the optimization of drug development and design (Makhouri \& Ghasemi, 2018).

One promising natural product for the development of pharmacological agents is Curcuma longa L. (Zingiberaceae). This herbaceous and perennial species originated in Asia and is distributed throughout the tropics. It is a rhizome-like pseudostem plant, popularly known as turmeric (Bortolucci et al., 2020). C. longa is commonly used in the food industry as a food coloring, seasoning, and condiment (Wang et al., 2014). The main classes of compounds that are identified in rhizomes of this species are curcuminoids (curcumin, demethoxycurcumin, and bisdesmethoxycurcumin) and oxygenated sesquiterpenes (Marchi et al., 2020). Its pharmacological properties, identified by preclinical studies, include antiinflammatory, gastroprotective, hepatoprotective, antiparasitic, antibacterial, antiviral, antifungal, anti-cancer, antiarthritic, antioxidant, hypolipidemic, and anti-human immunodeficiency virus effects (Araujo \& Leon, 2001; Bastos et al., 2009; Krup et al., 2013; $\mathrm{Yu}$ et al., 2002). Furthermore, the species also has actions on the immune system, sedative properties, and neuroprotective activity (Kim et al., 2014).

To identify potential dopaminergic ligands, the present study performed a molecular docking investigation of $\mathrm{D}_{2}$, $\mathrm{D}_{3}$, and $\mathrm{D}_{4}$ receptor interactions with active metabolites from $C$. longa using an in silico approach. We sought to identify possible compounds for drug development, following the good standards of scientific research methodology (Pereira et al., 2018).

\section{Methodology}

\subsection{Extract preparation and virtual library of compounds}

Rhizomes of Curcuma longa were collected in June and July 2016 at the Paranaense University Medicinal Garden (S2346'11.3"-W5316'41.2"; voucher specimen no. 2000). The extract preparation and phytochemical characterization were previously described (Marchi et al., 2020). 
Research, Society and Development, v. 10, n. 7, e59910716992, 2021

(CC BY 4.0) | ISSN 2525-3409 | DOI: http://dx.doi.org/10.33448/rsd-v10i7.16992

\subsection{Virtual library}

A virtual library of compounds was built using molecules that were identified in the phytochemical characterization of C. longa by gas chromatography coupled with mass spectrometry and high-performance liquid chromatography (Marchi et al. 2020). The three-dimensional structures were obtained from the PubChem (Kim et al., 2019) and Zinc15 (Sterling and Irwin, 2015) databases. A total of 92 molecules were obtained. The protocols that were validated by redocking were applied to the virtual screening of this library using three different programs, with four repetitions each.

\subsection{Biological targets selection}

The three-dimensional structures of $\mathrm{D}_{2}, \mathrm{D}_{3}$, and $\mathrm{D}_{4}$ receptors in complex with risperidone (RPN; Fig. 1A), eticlopride (ETC; Fig. 1B), and nemonapride (NMP; Fig. 1C) were obtained from the Protein Data Bank (PDB ID: 6cm4, 3pbl, and 5wiu, respectively). All small molecules and ions that were present in the solvent were then removed from the coordinates, except the 2112 structural water molecule in the $\mathrm{D}_{2}$ receptor structure.

Figure 1. (A) Three-dimensional structure of the D2 receptor in complex with RPN (PDB ID: 6cm4). (B) Three-dimensional structure of the D3 receptor in complex with ETC (PDB ID: 3pbl). (C) Three-dimensional structure of the D4 receptor in complex with NMP (PDB ID: 5wiu).

A)

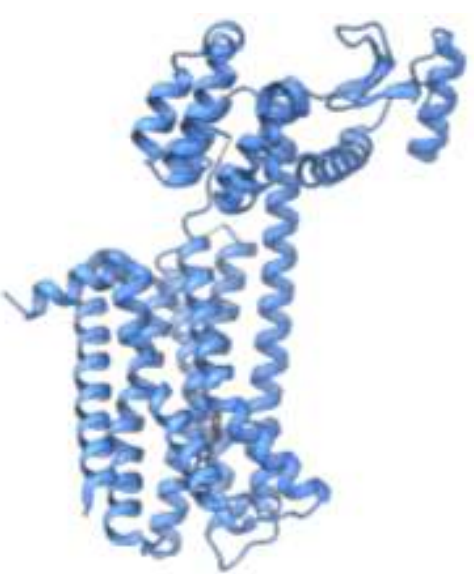

B)

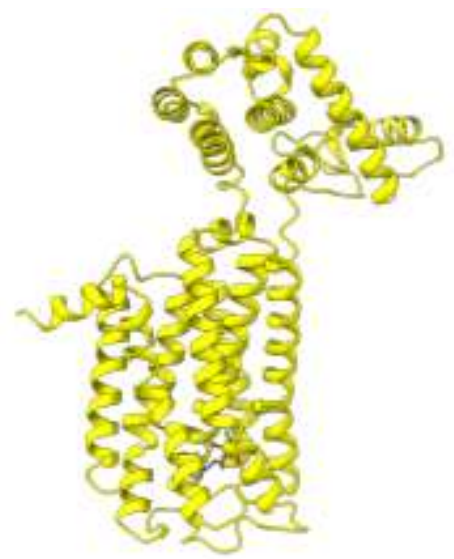

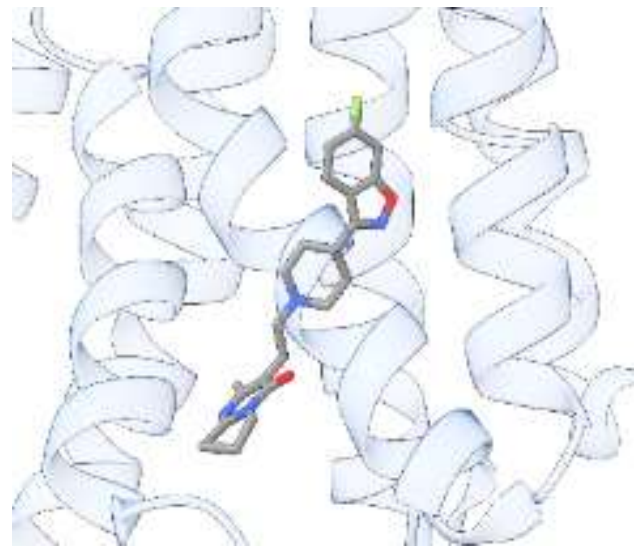

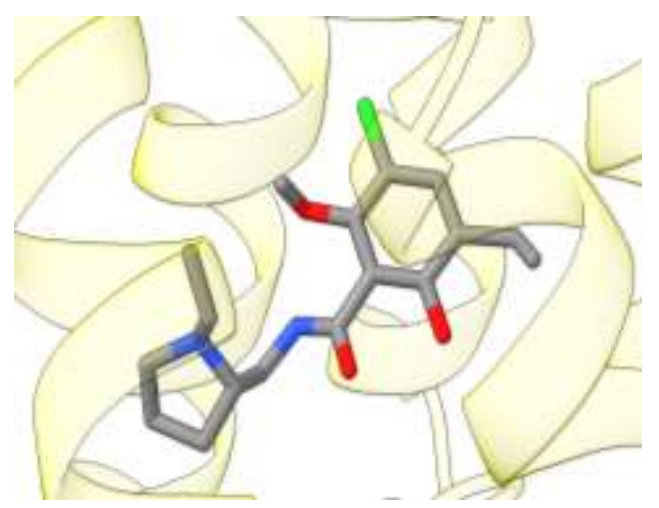


C)

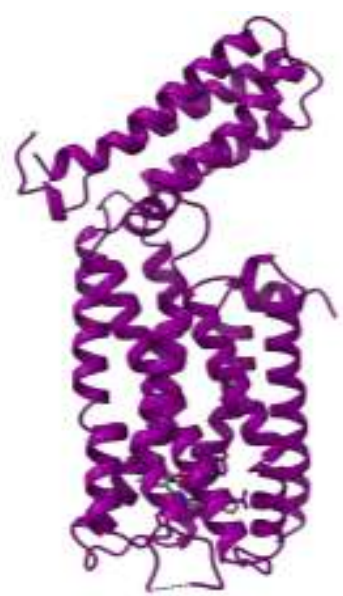

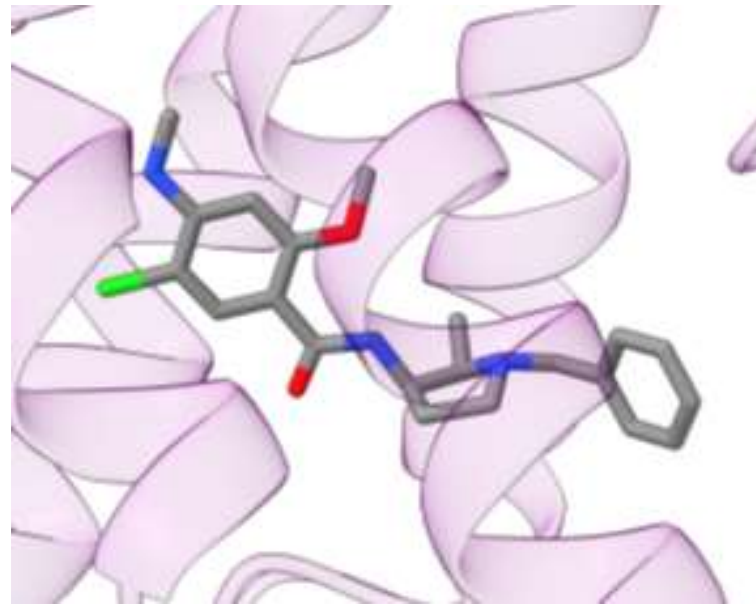

Source: Authors.

\subsection{Molecular docking analysis}

To perform the docking simulations, three programs were used: Autodock-v4.2.3 (Morris et al., 2009) and Autodock Vina (Trott \& Olson, 2010), both implemented in the PyRx-0.9 graphical interface (Dallakyan \& Olson, 2015), and Molegrov6.0 Virtual Docker (Thomsen \& Christensen, 2006). The parameters of each program were selected from the redocking of crystallographic ligands in their respective receptors. The protocols were considered validated when redocking returned poses with a root mean square deviation (RMSD) below $3 \AA$ relative to the original conformation of the receptor-ligand complex in four repetitions. In Autodock, the search box was centered on the crystallographic ligand at x, y, z coordinates of 7, $8,-9$ for $\mathrm{x}$, $0,-14,11$ for $\mathrm{y}$, and $-18,15,-16$ for $\mathrm{z}\left(\mathrm{D}_{2}, \mathrm{D}_{3}\right.$, and $\mathrm{D}_{4}$ receptors, respectively. For all three receptors, grid dimensions of 50, a resolution of $0.375 \AA$, 25 runs, and 2,500,000 energy evaluations were used. In Vina, the same coordinates and dimensions that are described above were used, and the exhaustiveness parameter was changed to 16 , and the modes parameter was changed to 25. In Molegro for the $\mathrm{D}_{2}$ receptor, Plants Score (grid) and Moldock Optmizer were used as ranking and search algorithms, with 10 runs and a $15 \AA$ search radius, respectively. For $\mathrm{D}_{3}$ and $\mathrm{D}_{4}$ receptors, the Iterated Simplex search algorithm was selected, and the other parameters were the same as those described above for the $\mathrm{D}_{2}$ receptor.

\section{Results and Discussion}

Molecular docking is an important tool that is useful for the rational design of drugs based on structures that can predict how a receptor interacts with a small-molecule ligand to form a stable complex (Raghu et al., 2018). This method has been useful for developing several drugs without expending excessive effort or investment in research, and these drugs subsequently underwent preclinical studies and clinical trials for validation (Chaurasiya et al., 2016; Shruthy \& Shakkela, 2014). In the present study, molecular docking was used to simulate in silico interactions between biologically active metabolites from $C$. longa with $\mathrm{D}_{2}, \mathrm{D}_{3}$, and $\mathrm{D}_{4}$ receptors to identify possible new therapeutic targets, which appears to be a common link between neurodegenerative and neuropsychiatric disorders.

Dopamine has been intensively studied as a key neurotransmitter in the central nervous system. Many studies have sought to understand the physiological processes and define the mechanisms of several pathologies, including PD, schizophrenia, substance dependence, and attention-deficit/hyperactivity disorder (Pan et al., 2019; Yang \& Tsai, 2017). Subtypes of DA receptors have high amino acid sequence homogeneity and differ in their distribution, expression, affinity, and functional properties, thus creating challenges in developing receptor subtype-selective agonists and antagonists (Bueschbell et 
al., 2019; Missale et al., 1998; Neve et al., 2004; Yang et al., 2020). The lack of subtype specificity is related to several side effects that are commonly observed in the treatment of parkinsonian and schizophrenic patients (Briggs et al., 2008; Peschanski et al., 1994; Reichmann, 2016). For some diseases, such as PD and schizophrenia, the therapeutic arsenal only provides symptomatic relief, without significantly altering the underlying pathophysiology (Cuny, 2012; Hou et al., 2019). Thus, it is urgent to search for new compounds from many sources, including drug synthesis, existing drugs, and natural products, that act on pathways that are involved in neurodegenerative and neuropsychiatric disorders and are safer and more effective for the treatment of these diseases (Durães et al., 2018).

The present study employed redocking validation with risperidone, eticlopride, and nemonapride and $\mathrm{D}_{2}, \mathrm{D}_{3}$, and $\mathrm{D}_{4}$ receptor binding sites, respectively, to determine whether the docking protocol is acceptable (Table 1). The repetitions returned poses with an RMSD below $3 \AA$, thereby indicating that the protocols were validated and could be applied to screening the virtual library.

Table 1. Redocking study of risperidone (RPN), eticlopride (ETC), and nemonapride (NMP) at D2, D3, and D4 binding sites, respectively.

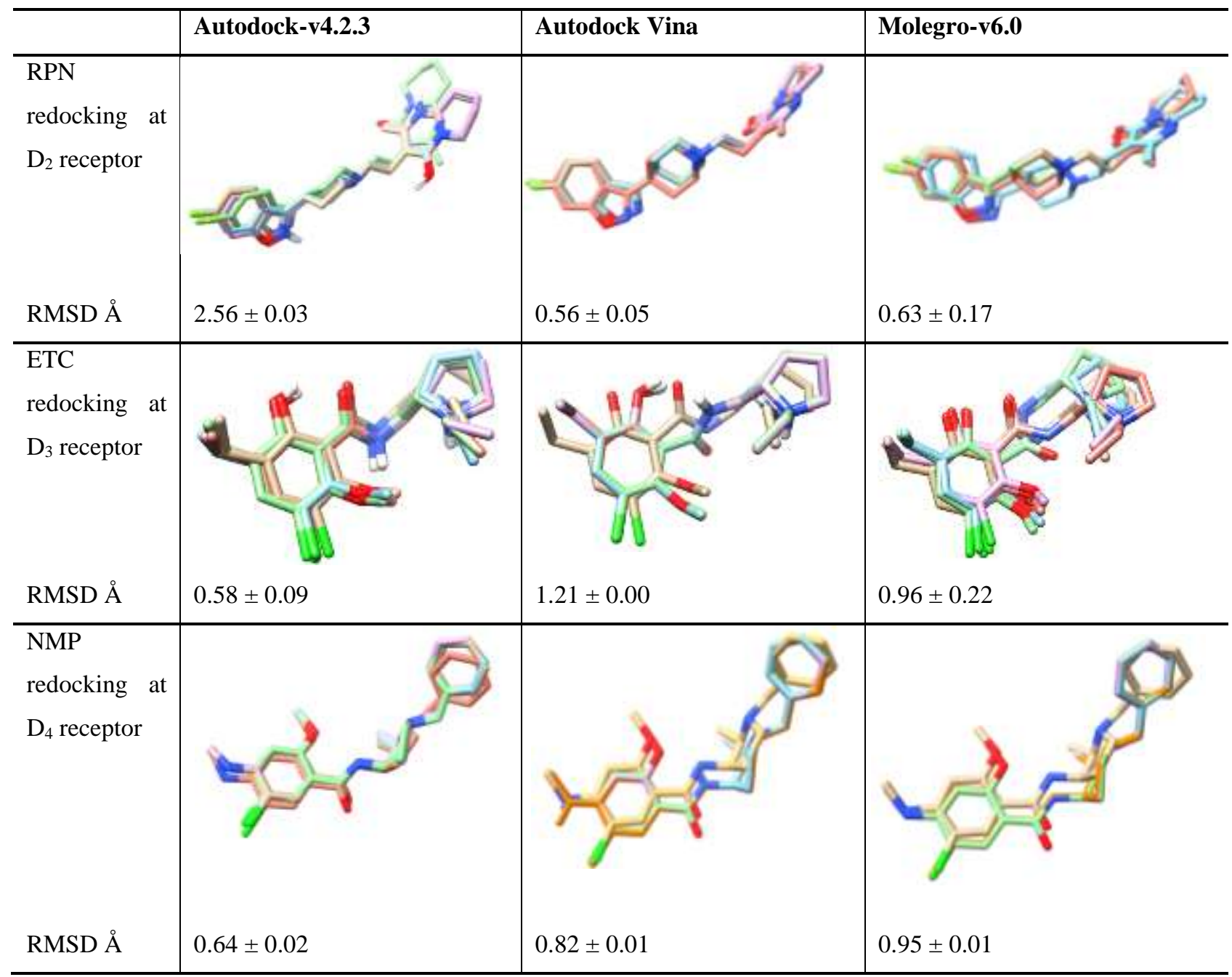

Source: Authors.

$\mathrm{D}_{2}$ receptors are highly expressed in striatopallidal medium spiny neurons in the external globus pallidus, nucleus accumbens core, ventral tegmental area, and substantia nigra pars compacta. They are expressed in lower concentrations in the 
amygdala, cerebral cortex, hippocampus, and pituitary (Mishra et al., 2018; Surmeier et. al., 2007). Two isoforms of $\mathrm{D}_{2}$ receptors, $\mathrm{D}_{2}$ long and $\mathrm{D}_{2}$ short, are expressed mainly postsynaptically and presynaptically, respectively. Postsynaptic $\mathrm{D}_{2}$ receptors mediate behavioral and extrapyramidal activity. Presynaptic $\mathrm{D}_{2}$ receptors decrease dopamine release, resulting in a decrease in locomotor activity (Hisahara \& Shimohama, 2011). The hyperactivity of dopamine at $\mathrm{D}_{2}$ receptors in the mesolimbic pathway is related to manifestations of positive symptoms of schizophrenia (Brisch et al., 2014).

$\mathrm{D}_{3}$ receptors are abundantly distributed in mesolimbic areas, including the nucleus accumbens, the olfactory tubercle, the amygdala, islands of Calleja, and the striatum (Gurevich \& Joyce, 1999; Jaber et al., 1996), and their activation or inhibition is related to symptoms of neurodegenerative and neuropsychiatric diseases, including emotional, behavioral, motivational, and memory fluctuations (Yang et al., 2020).

$\mathrm{D}_{4}$ receptors are primarily expressed on pyramidal neurons and interneurons in the prefrontal cortex, but their localization is also found on medium spiny neurons in the basal ganglia (striatum and nucleus accumbens core), throughout the limbic system, and in the thalamus in rodents (Gan et al., 2004; Mrzljak et al., 1996; Tarazi et al., 2004).

Dopamine receptors have long been considered critical players in PD and schizophrenia. In PD, the loss of dopaminergic neurons in the substantia nigra pars compacta leads to dopamine deficiency in the putamen and caudate nucleus, producing classic motor symptoms of PD, such as tremors, trouble moving, and fatigue (Alexander, 2004). Treatment for PD mainly involves dopaminergic-based strategies, which currently remain the best symptomatic treatment to improve quality of life (Miguelez et al., 2020). However, these therapies are limited by various side effects. New alternative treatment strategies, alone or combined with currently available synthetic drugs, are needed.

Schizophrenia is associated with the hyperactivity of dopaminergic systems (Brunelin et al., 2013). Currently available medications focus on the blockade of overstimulated dopamine receptors. For the therapeutic care of schizophrenia patients, these medications are generally effective for treating positive symptoms, but they have strong side effects (Grace, 2012; Miodownik et al., 2019).

C. longa is widely studied because curcumin has been shown to have diverse molecular mechanisms that underlie its beneficial effects in neurological diseases (Farooqui \& Farooqui, 2019; Ji \& Shen, 2014; Mythri \& Bharath, 2012; Miodownik et al., 2019). It contains several phytocompounds with potential biological activity. In the present study, of the 92 molecules that were analyzed, four were consistently ranked among those with the highest affinity for the three dopamine receptors (Supplementary Tables S1, S2, and S3). These molecules included stigmasterol (Fig. 2A), $\beta$-sitosterol (Fig. 2B), cholest-5-en3-one (Fig. 2C), and cholestan-3-ol,2-methylene-(3 $\beta, 5 \alpha)$ (Fig. 2D). 
Figure 2. (A) Stigmasterol. (B) $\beta$-sitosterol. (C) Cholest-5-en-3-one. (D) Cholestan-3-ol,-2-methylene-(3 $\beta, 5 \alpha)$.
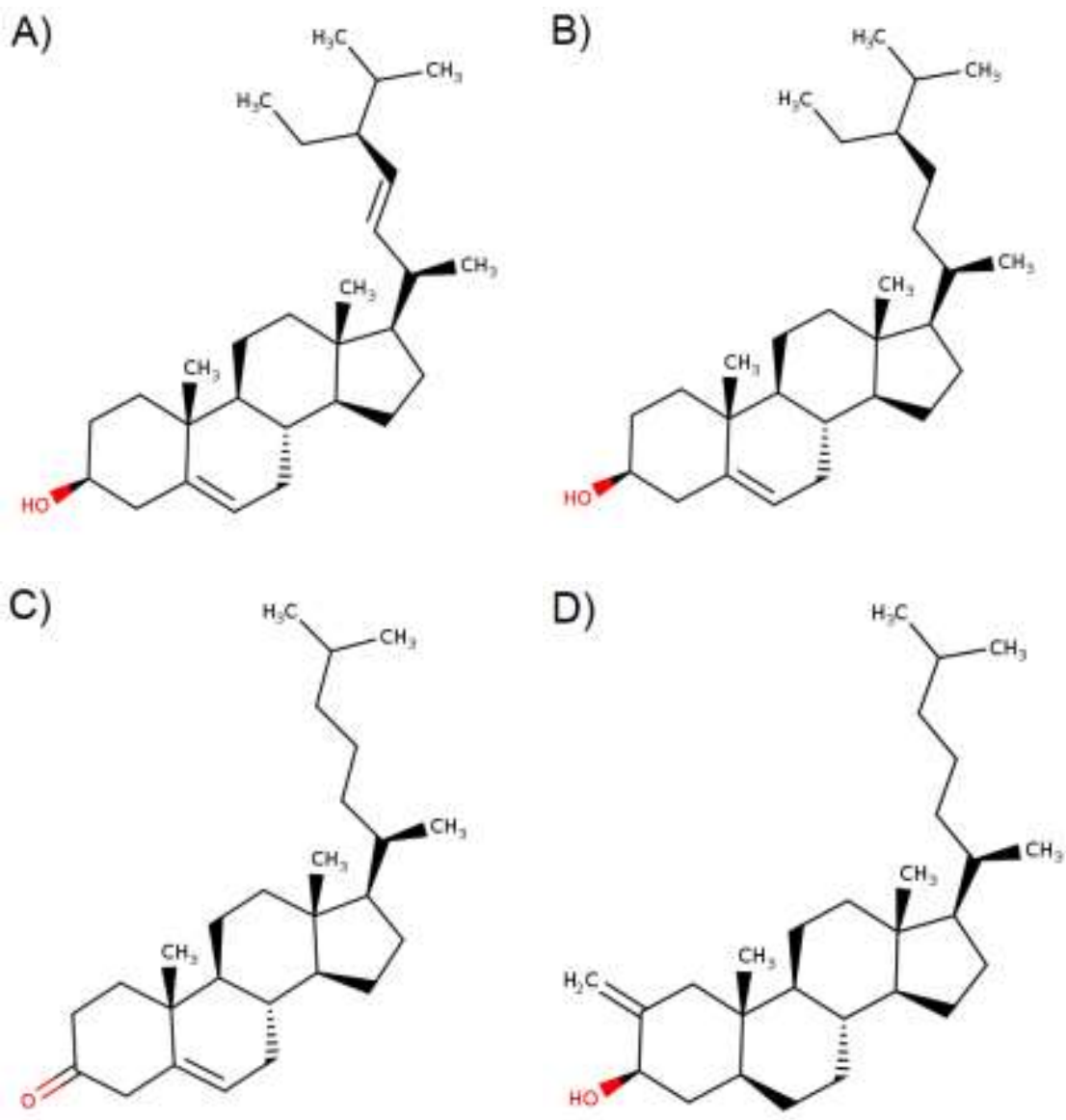

Source: Authors.

Tables 2 show the docking results of stigmasterol, $\beta$-sitosterol, cholest-5-en-3-one, and cholestan-3-ol,2-methylene$(3 \beta, 5 \alpha)$ ligands at the $\mathrm{D}_{2}$ receptor.

Table 2. Virtual screening of stigmasterol, $\beta$-sitosterol, cholest-5-en-3-one, and cholestan-3-ol,2-methylene-(3 $\beta, 5 \alpha)$ ligands at the $\mathrm{D}_{2}$ receptor.

\begin{tabular}{llccc}
\hline PubChem CID & Name & Autodock-v4.2.3 & Autodock Vina & Molegro-v6.0 \\
\hline \multirow{2}{*}{5280794} & risperidone & $-13.03 \pm 0.01$ & $-103.98 \pm 3.70$ & $-11.8 \pm 0.00$ \\
222284 & stigmasterol & $-12.85 \pm 0.23$ & $-82.40 \pm 1.16$ & $-8.70 \pm 0.00$ \\
9908107 & $\beta$-sitosterol & $-12.69 \pm 0.21$ & $-86.07 \pm 0.65$ & $-8.90 \pm 0.05$ \\
& cholest-5-en-3-one & $-12.53 \pm 0.08$ & $-79.94 \pm 1.41$ & $-8.75 \pm 0.06$ \\
22213932 & cholestan-3-ol,2-methylene- & & & $-8.23 \pm 0.05$ \\
\hline
\end{tabular}

Source: Authors.

Tables 3 show the docking results of stigmasterol, $\beta$-sitosterol, cholest-5-en-3-one, and cholestan-3-ol,2-methylene$(3 \beta, 5 \alpha)$ ligands at the $\mathrm{D}_{3}$ receptor. 
Table 3. Virtual screening of stigmasterol, $\beta$-sitosterol, cholest-5-en-3-one, and cholestan-3-ol,2-methylene-(3 $\beta, 5 \alpha)$ ligands at the $\mathrm{D}_{3}$ receptor.

\begin{tabular}{lllll}
\hline PubChem CID & Name & Autodock-v4.2.3 & Autodock Vina & Molegro-v6.0 \\
\hline \multirow{2}{*}{5280794} & eticlopride & $-9.42 \pm 0.07$ & $-85.14 \pm 0.04$ & $-8.40 \pm 0.00$ \\
222284 & stigmasterol & $-13.39 \pm 0.11$ & $-91.97 \pm 0.02$ & $-10.00 \pm 0.00$ \\
9908107 & $\beta$-sitosterol & $-13.30 \pm 0.14$ & $-96.71 \pm 0.19$ & $-9.33 \pm 0.13$ \\
& cholest-5-en-3-one & $-12.63 \pm 0.02$ & $-91.98 \pm 0.15$ & $-9.58 \pm 0.52$ \\
22213932 & cholestan-3-ol,2-methylene- & & & $-9.35 \pm 0.19$ \\
\hline
\end{tabular}

Source: Authors.

Tables 4 show the docking results of stigmasterol, $\beta$-sitosterol, cholest-5-en-3-one, and cholestan-3-ol,2-methylene$(3 \beta, 5 \alpha)$ ligands at the $\mathrm{D}_{4}$ receptor.

Table 4. Virtual screening of stigmasterol, $\beta$-sitosterol, cholest-5-en-3-one, and cholestan-3-ol,2-methylene-( $3 \beta, 5 \alpha)$ ligands at the $\mathrm{D}_{4}$ receptor.

\begin{tabular}{llccc}
\hline PubChem CID & Name & Autodock-v4.2.3 & Autodock Vina & Molegro-v6.0 \\
\hline \multirow{2}{*}{5280794} & nemonapride & $-11.30 \pm 0.02$ & $-90.12 \pm 0.05$ & $-10.20 \pm 0.00$ \\
222284 & stigmasterol & $-12.78 \pm 0.08$ & $-93.39 \pm 1.16$ & $-10.20 \pm 0.00$ \\
9908107 & $\beta$-sitosterol & $-12.49 \pm 0.14$ & $-92.05 \pm 0.21$ & $-9.68 \pm 0.13$ \\
& cholest-5-en-3-one & $-12.38 \pm 0.05$ & $-85.44 \pm 0.05$ & $-9.48 \pm 0.10$ \\
22213932 & cholestan-3-ol,2-methylene- & & & $-10.00 \pm 0.00$ \\
\hline
\end{tabular}

Source: Authors.

Stigmasterol is a phytoestrogen that is naturally found in many herbs, including Akebia quinata, Gypsophila oldhamiana, Emilia sonchifolia, Eucalyptus globules, Aralia cordata, Emilia sonchifolia, Theobroma cacao L., and C. longa (Marchi et al., 2020; Awad et al., 2009; Kaur et al., 2011; Yadav et al., 2018). Stigmasterol has been reported to possess many pharmacological activities (Ayati et al., 2019).

The neurological effects of stigmasterol in vitro and in vivo have been reported. Haque et al. (2019) investigated the role of stigmasterol in neuroprotection and neuronal viability in hypoxia reoxygenation-induced injury in hippocampal cultures. The authors found that stigmasterol exerted a neuroprotective effect at a concentration of $20 \mu \mathrm{M}$. Another study found that stigmasterol $(10 \mathrm{mg} / \mathrm{kg})$ promoted cognitive improvements in animals that were subjected to a passive avoidance task and the Morris water maze (Park et al., 2012). In this study, stigmasterol interacted with $\mathrm{D}_{2}, \mathrm{D}_{3}$, and $\mathrm{D}_{4}$ receptors. Formation of the most stable binding complex with $\mathrm{D}_{3}$ and $\mathrm{D}_{4}$ receptors featured neuroactive potential for improving brain functions. In Fig. 3 , residues can be seen at least $4 \AA$ away from stigmasterol for $\mathrm{D}_{2}, \mathrm{D}_{3}$, and $\mathrm{D}_{4}$ receptors. 
Research, Society and Development, v. 10, n. 7, e59910716992, 2021

(CC BY 4.0) | ISSN 2525-3409 | DOI: http://dx.doi.org/10.33448/rsd-v10i7.16992

Figure 3. Stigmasterol docking at (A) $\mathrm{D}_{2}$ receptor (residues $4 \AA$ away from the ligand), (B) $\mathrm{D}_{3}$ receptor (residues $4 \AA$ away from the ligand), and (C) $\mathrm{D}_{4}$ receptor (residues $4 \AA$ away from the ligand).

A)

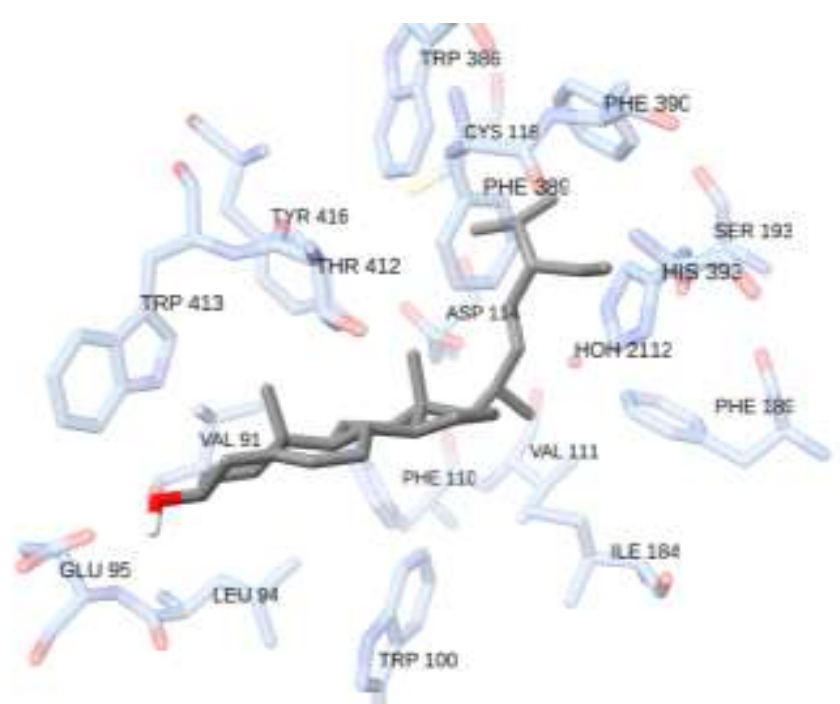

B)

C)
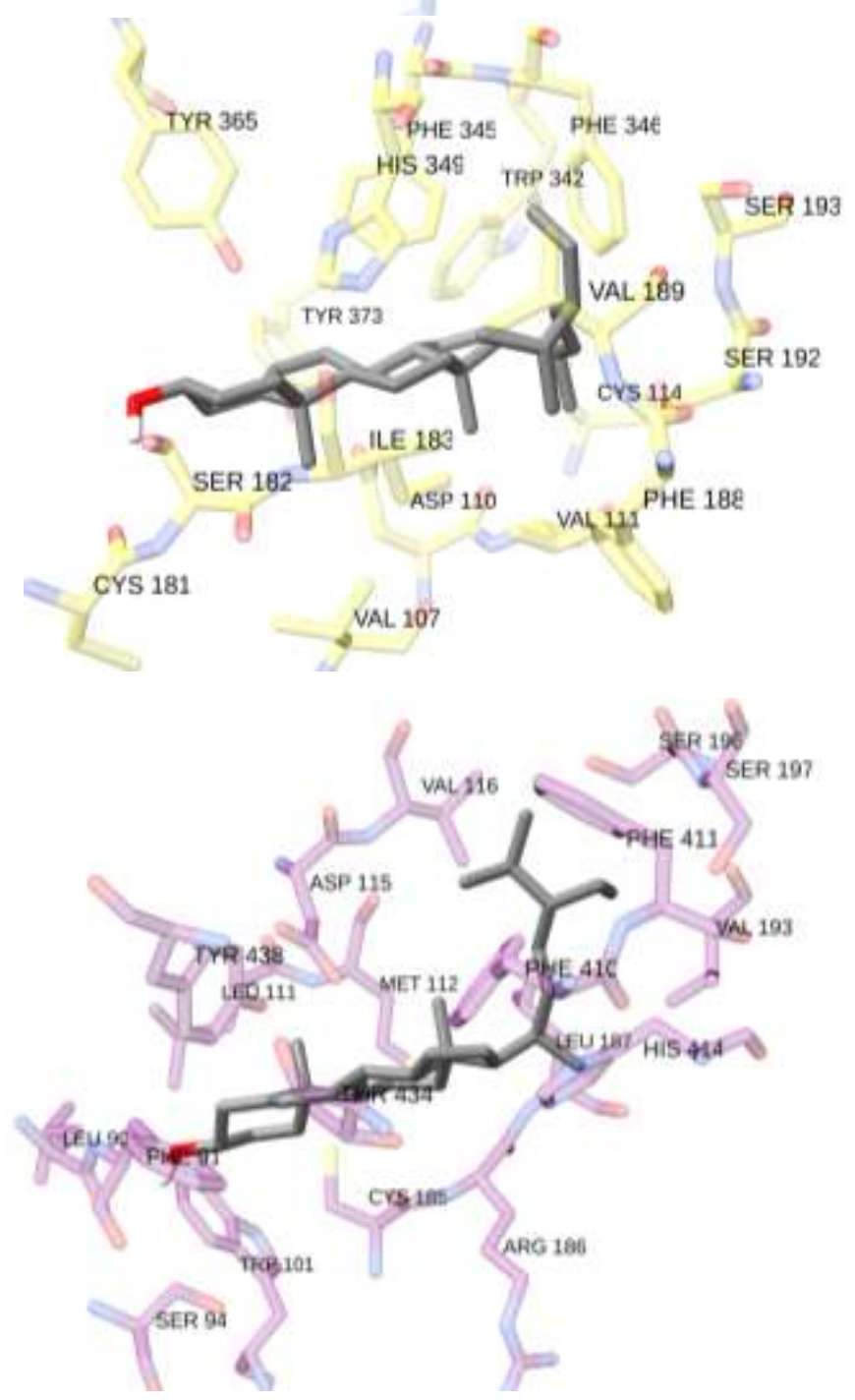

Source: Authors. 
The molecular docking study also supported the binding of $\beta$-sitosterol, a plant sterol, with $\mathrm{D}_{2}, \mathrm{D}_{3}$, and $\mathrm{D}_{4}$ receptors. Several studies reported various neuroprotective and antioxidant effects of $\beta$-sitosterol (Vivancos \& Moreno, 2005; Baskar et al., 2012; Muhammad et al., 2017). Additionally, the antidepressant activity of $\beta$-sitosterol was evaluated in the tail suspension test and forced swim test in mice. The authors concluded that $\beta$-sitosterol exhibits antidepressant-like effects that are mediated by the serotoninergic, dopaminergic, and $\gamma$-aminobutyric acid-ergic systems (Yin et al., 2018). Cholest-5-en-3-one and

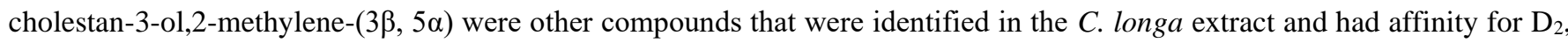
$\mathrm{D}_{3}$, and $\mathrm{D}_{4}$ receptors. These findings should prompt further in vitro and in vivo studies to prove their biological activity.

Finally, the current pharmaceutical armamentarium against neurodegenerative (Youdim \& Buccafusco, 2005) and neuropsychiatric (Miodownik et al., 2019) diseases remains limited in terms of both treatment outcome and disease modification. The present results demonstrate that four $C$. longa compounds interact with dopamine receptors that are involved in the pathophysiology of several neurodegenerative and neuropsychiatric disorders.

\section{Conclusion}

Stigmasterol, $\beta$-sitosterol, cholest-5-en-3-one, and cholestan-3-ol,2-methylene-(3 $\beta, 5 \alpha)$ are metabolites of $C$. longa that had the highest probability of binding dopamine $\mathrm{D}_{2}, \mathrm{D}_{3}$, and $\mathrm{D}_{4}$ receptors. Our findings may contribute to further drug development.

The present study has limitations. We performed only a virtual throughput screening. Further high-throughput screening is required, in addition to studies with animal models and clinical trials to further confirm that $C$. longa metabolites may be potential drug candidates.

\section{Acknowledgments}

The authors are grateful to Universidade Paranaense, Graduate Program in Medicinal Plants and Phytotherapeutics in Basic Attention, and Graduate Program in Animal Science with Emphasis on Bioactive Products for financial support. This work was also supported by grants from Fundação Araucária (FUNDAÇÃO ARAUCÁRIA; no. 47661.491.48325.12122016) and Paranaense University.

\section{References}

Alexander, G. E. (2004). Biology of Parkinson's disease: pathogenesis and pathophysiology of a multisystem neurodegenerative disorder. Dialogues in clinical neuroscience, 6(3), 259-280. Doi: 10.31887/DCNS.2004.6.3/galexander.

Alfio, S. T., Laudani, S., Contarini, G., Luca, A. D., Geraci, F., Managò, F., Papaleo, F., Salomone, S., Drago, F. \& Leggio, G.M. (2020). Dopamine, Cognitive Impairments and Second-Generation Antipsychotics: From Mechanistic Advances to More Personalized Treatments. Pharmaceuticals. 13, 365. Doi: $10.3390 / \mathrm{ph} 13110365$.

Araújo, C. A. C. \& Leon, L. L. (2001). Biological activities of Curcuma longa L. Memórias do Instituto Oswaldo Cruz. 96(5), 723-728. Doi: 10.1590/S007402762001000500026 .

Awad, A. B., Chan, K. C., Downie, A. C. \& Fink, C. S. (2009). Peanuts as a source of $\beta$-sitosterol, a sterol with anticancer properties. Nutrition and Cancer. 36(2), 238-241. Doi: 10.1207/S15327914NC3602_14.

Ayati1, Z., Ramezani, M., Amiri, M.S., Moghadam, A.T., Rahimi, H., Abdollahzade, A., Sahebkar, A. \& Emami1, S.A. (2019). Ethnobotany, Phytochemistry and Traditional Uses of Curcuma spp. and Pharmacological Profile of Two Important Species (C. longa and C. zedoaria): A Review. Current Pharmaceutical Design. 25, 871-935. Doi: 10.2174/1381612825666190402163940.

Badgaiyan, R. (2016). Dynamic molecular imaging guides treatment options for attention deficit hyperactive disorder (ADHD). Journal of Nuclear Medicine. 57 (2), 272.

Baskar, A. A., Numair, K. S., Paulraj, G. \& Alsaif, M. (2012). Ignacimuthu S. $\beta$-sitosterol prevents lipid peroxidation and improves antioxidant status and histoarchitecture in rats with 1,2-dimethylhydrazine-induced colon cancer. Journal of Medicinal Food. 15(4), 335-43. Doi: 10.1089/jmf.2011.1780. 
Bastos, D. H. M., Rogero, M. M. \& Arêas, J. A. G. (2009). Mecanismos de ação de compostos bioativos dos alimentos no contexto de processos inflamatórios relacionados à obesidade. Arquivos Brasileiros de Endocrinologia \& Metabologia. 53(5), 646-656. Doi: 10.1590/S0004-27302009000500017.

Bortolucci, W. C., Trettel, J. R., Bernardi, D. M, Souza, M. M. Q, Lopes, A. D., Lovato, E. C. W, Lívero, F. A. R., Silva, G. J., Magalhães, H. M., Souza, S.G.H., Gazim, Z.C. \& Colauto, N.B. (2020). Therapeutic potential of Zingiberaceae in Alzheimer's disease. Boletin Latinoamericano y Del Caribe de Plantas Medicinales y Aromáticas. 19 (5), 428-465. Doi: 10.37360/blacpma.20.19.5.30.

Briggs, A., Wild, D., Lees, M., Reaney, M., Dursun S., Parry, D. \& Mukherjee, J. (2008). Impact of schizophrenia and schizophrenia treatment-related adverse events on quality of life: direct utility elicitation. Health and Quality of Life Outcomes. 6, 105. Doi: 10.1186/1477-7525-6-105.

Brisch, R., Saniotis, A., Wolf, R., Bielau, H., Bernstein, H. G., Steiner, J., Bogerts, B., Braun, K., Jankowski, Z., Kumaratilake, J., Henneberg, M. \& Gos, T. (2014). The role of dopamine in schizophrenia from a neurobiological and evolutionary perspective: old fashioned, but still in vogue. Frontiers in psychiatry, 5, 47. Doi: 10.3389/fpsyt.2014.00047.

Broft, A., Slifstein, M., Osborne, J., Kothari, P., Morim, S., Shingleton, R., Kenney, L., Vallabhajosula, S., Attia, E., Martinez, D. \& Walsh, B. T. (2015). Striatal DA type 2 receptor availability in anorexia nervosa. Psychiatry Research: Neuroimaging. 233(3), 380-387. Doi: 10.1016/j.pscychresns.2015.06.013.

Brunelin, J., Fecteau, S. \& Suaud-Chagny, M.F. (2013). Abnormal striatal DA transmission in schizophrenia. Current Medicinal Chemistry. 20(3), 397-404. Doi: 10.2174/0929867311320030011.

Bueschbell, B., Barreto, C., Preto, A. J., Schiedel, A.C. \& Moreira, I. S. (2019). A Complete Assessment of DA Receptor- Ligand Interactions through Computational Methods. Molecules (Basel, Switzerland). 24(7), 1196. Doi: 10.3390/molecules24071196.

Chaurasiya, S., Kaur, P., Nayak, S. K. \& Khatik, G. L. (2016). Virtual screening for identification of novel potent EGFR inhibitors through AutoDock Vina molecular modeling software. Journal of Chemical and Pharmaceutical Research. 8(4), 353-360.

Conn, K. A., Burne, T. H. J. \& Kesby, J. P. (2020). Subcortical DA and Cognition in Schizophrenia: Looking Beyond Psychosis in Preclinical Models. Frontiers in Neuroscience. 14, 542. Doi: 10.3389/fnins.2020.00542. eCollection 2020.

Cuny, G. D. (2012). Neurodegenerative diseases: challenges and opportunities. Future Medicinal Chemistry, 4(13), 1647-1649. Doi: 10.4155/fmc.12.123.

Cunha, C., Wietzikoski, E. C., Bortolanza, M., Dombrowski, P. A., Dos Santos, L. M., Boschen, S. L., Miyoshi, E., Vital, M. A., Boerngen-Lacerda, R. \& Andreatini, R. (2009a). Non-motor function of the midbrain DArgic neurons. Journal of neural transmission. Supplementum. (73), 147-160.

Cunha, C., Wietzikoski, E. C., Dombrowski, P., Bortolanza, M., Santos, L. M., Boschen, S. L. \& Miyoshi, E. (2009b). Learning processing in the basal ganglia: a mosaic of broken mirrors. Behavioural Brain Research. 199(1), 157-170. Doi: 10.1016/j.bbr.2008.10.001.

Dallakyan, S., \& Olson, A. J. (2015). Small-molecule library screening by docking with PyRx. Methods in molecular biology. 1263, 243-250. Doi: 10.1007/978-1-4939-2269-7_19.

Dong, M. X., Chen, G. H. \& Hu, L. (2020). DArgic System Alteration in Anxiety and Compulsive Disorders: A Systematic Review of Neuroimaging Studies. Frontiers in Neuroscience. 14, 608520. Doi: 10.3389/fnins.2020.608520.

Durães, F., Pinto, M. \& Sousa, E. (2018). Old drugs as new treatments for neurodegenerative diseases. Pharmaceuticals (Basel). 11(2), 44. Doi: $10.3390 /$ ph1 1020044

Farooqui, A. A. \& Farooqui, T. (2019). Chapter 18 - Therapeutic Potentials of Curcumin in Parkinson's Disease, Editor(s): Tahira Farooqui, Akhlaq A. Farooqui, Curcumin for Neurological and Psychiatric Disorders, Academic Press, 333-344. Doi:10.1016/B978-0-12-815461-8.00018-9.

Fernandes, L. C., Santos, A. G., Sampaio, T. B., Sborgi, S., Prediger, R., Ferro, M. M., Franco, G., Lipinski, L. \& Miyoshi, E. (2020). Exposure to paraquat associated with periodontal disease causes motor damage and neurochemical changes in rats. Human \& experimental toxicology. 40(1), 81-89. Doi: $10.1177 / 0960327120938851$.

Fontoura, J. L., Baptista, C., Pedroso, F. B., Pochapski, J.A., Miyoshi, E. \& Ferro, M. M. (2017). Depression in Parkinson's Disease: The Contribution from Animal Studies. Parkinson's Disease. 9124160.

Galaj, E., Newman, A. H. \& Xi, Z. X. (2020). Dopamine D3 receptor-based medication development for the treatment of opioid use disorder: Rationale, progress, and challenges. Neuroscience \& Biobehavioral Reviews. 114, 38-52. Doi: 10.1016/j.neubiorev.2020.04.024.

Gan, L., Falzone, T. L., Zhang, K., Rubinstein, M., Baldessarini, R. J. \& Tarazi, F. I. (2004). Enhanced expression of dopamine D(1) and glutamate NMDA receptors in dopamine $\mathrm{D}(4)$ receptor knockout mice. Journal of molecular neuroscience. 22(3), 167-178. Doi: 10.1385/JMN:22:3:167.

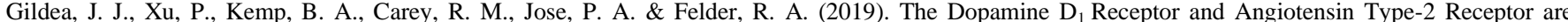
Required for Inhibition of Sodium Transport Through a Protein Phosphatase 2A Pathway. Hypertension. 73(6), 1258-1265. Doi: 10.1161/HYPERTENSIONAHA.119.12705

Grace, A.A. (2012). DA system dysregulation by the hippocampus: implications for the pathophysiology and treatment of schizophrenia. Neuropharmacology. 62(3), 1342-8. Doi: 10.1016/j.neuropharm.2011.05.011.

Grimes, D., Fitzpatrick, M., Gordon, J., Miyasaki, J., Fon, E.A., Schlossmacher, M., Suchowersky, O., Rajput, A., Lafontaine, A.L, Mestre, T., Cresswell, S A., Kalia, S. K., Schoffer, K., Zurowski, M., Postuma, R. B., Udow, S., Fox, S., Barbeau, P. \& Hutton, B. (2019). Canadian guideline for Parkinson disease. CMAJ. 9(191), E989-E1004. Doi: 10.1503/cmaj.181504.

Gurevich, E. V. \& Joyce, J. N. (1999). Distribution of dopamine D3 receptor expressing neurons in the human forebrain: comparison with D2 receptor expressing neurons. Neuropsychopharmacology. 20(1), 60-80. Doi: 10.1016/S0893-133X(98)00066-9. 
Haque, N., Hannan, A. \& Dash, R. (2019). Il Soo Moon Natural LXR $\beta$ agonist stigmasterol confers protection against excitotoxicity after hypoxiareoxygenation $(\mathrm{H} / \mathrm{R})$ injury via regulation of mitophagy in primary hippocampal neurons. bioRxiv. 707059. Doi: 10.1101/707059.

Hisahara, S. \& Shimohama, S. (2011). DA receptors and Parkinson's disease. International journal of medicinal chemistry. 403039. Doi: $10.1155 / 2011 / 403039$.

Horga, G., Cassidy, C.M., Xu, X., Moore, H., Slifstein, M., Van Snellenberg, J. X. \& Abi-Dargham, A. (2016). Dopamine-Related Disruption of Functional Topography of Striatal Connections in Unmedicated Patients With Schizophrenia. JAMA Psychiatry. 73 (8), 862-870. Doi: 10.1001/jamapsychiatry.2016.0178.

Hou, H., Wang, C., Jia, S., Hu, S., \& Tian, M. (2014). Brain dopaminergic system changes in drug addiction: a review of positron emission tomography findings. Neuroscience Bulletin. 30, 765-776. Doi: 10.1007/s12264-014-1469-5.

Hou, Y., Dan, X., Babbar, M., Wei, Y., Hasselbalch, S.G., Croteau, D.L. \& Bohr, V.A. (2019). Ageing as a risk factor for neurodegenerative disease. Nature Reviews Neurology. 15(10), 565-581. Doi: 10.1038/s41582-019-0244-7.

Hynes, C., McWilliams, S., Clarke, M., Fitzgerald, I., Feeney, L., Taylor, M., Boland, F. \& Keating, D. (2020). Check the effects: systematic assessment of antipsychotic side-effects in an inpatient cohort. Therapeutic advances in psychopharmacology. 10, 2045125320957119. Doi: 10, 2045125320957119.

Jaber, M., Robinson, S.W., Missale, C. \& Caron, M.G. (1996). Dopamine receptors and brain function. Neuropharmacology. 35, 1503-1519. Doi: $10.1016 / \mathrm{s} 0028-3908(96) 00100-1$.

Ji, H. F. \& Shen, L. (2014). The multiple pharmaceutical potential of curcumin in Parkinson's disease. CNS \& neurological disorders drug targets. 13(2), 36973. doi: $10.2174 / 18715273113129990077$.

Kaur, N., Chaudhary, J., Jain, A. \& Kishore, L. (2011). Stigmasterol: a comprehensive review. International Journal of Pharmaceutical Sciences and Research. 2(9), 2259-65.

Kim, M. H., Kim, S. H. \& Yang, W. M. (2014). Mechanisms of Action of Phytochemicals from Medicinal Herbs in the Treatment of Alzheimer's Disease. Planta medica. 80 (15), 1249-1258. Doi: 10.1055/s-0034-1383038.

Kim, S., Chen, J., Cheng, T., Gindulyte, A., He, J., He, S., Li, Q., Shoemaker, B. A., Thiessen, P. A., Yu, B., Zaslavsky, L., Zhang, J. \& Bolton, E. E. (2019). PubChem 2019 update: improved access to chemical data. Nucleic Acids Research. 47(D1), D1102-D1109. Doi: 10.1093/nar/gky1033.

Kim, Y. C., Alberico, S. L., Emmons, E. \& Narayanan, N. S. (2015). New therapeutic strategies targeting D1-type dopamine receptors for neuropsychiatric disease. Frontiers in biology. 10(3), 230-238. Doi: 10.1007/s11515-015-1360-4.

Krup, V., Prakash, H. L. \& Harini, A. (2013). Pharmacological activities of turmeric (Curcuma longa linn): A review. Homeopathy \& Ayurvedic Medicine. 2(4), 1000134. Doi: 10.4172/2167-1206.1000133.

Li, H., Yang, P., Knight, W., Guo, Y., Perlmutter, J.S., Benzinger, T. L. S., Morris, J. C. \& Xu, J. (2020). The interactions of DA and oxidative damage in the striatum of patients with neurodegenerative diseases. Journal of neurochemistry. 152(2), 235-251. Doi: 10.1111/jnc.14898

Liu, G. J., Wu, L., Wang, S. L., Xu, L. L., Chang, L. Y. \& Wang, Y. F. (2016). Efficacy of pramipexole for the treatment of primary restless leg syndrome: a systematic review and meta-analysis of randomized clinical trials. Clinical therapeutics. 38(1), 162-179.e6. Doi: 10.1016/j.clinthera.2015.10.010.

Makhouri, F.R. \& Ghasemi, J.B. (2018). In Silico Studies in Drug Research Against Neurodegenerative Diseases. Current neuropharmacology, 16(6), 664725. Doi: 10.2174/1570159X15666170823095628.

Marchi, J. P, Lívero, F. A. R., Soares, A. A., Silva, G. J., Soares, A. K. V., Giarolo, C. M., Jacomassi, E., Souza, L. M., Bortolucci, W. C., Gazim, Z. C., Campos, C. F. A. A., Gonçalves, J. E., Alferes, C. S., Wietzikoski, S. \& Lovato, E. C. W. (2021). Influence of different preparation techniques on the composition and antioxidant action of curcumin and curcuminoids. Boletín Latinoamericano y del Caribe de Plantas Medicinales, in press.

Martel, J.C. \& McArthur, S.G. (2020). Dopamine Receptor Subtypes, Physiology and Pharmacology: New Ligands and Concepts in Schizophrenia. Frontiers in Pharmacology. 11, 1003. Doi: 10.3389/fphar.2020.01003.

Martinez, V.J., Asico, L.D., Jose, P.A. \& Tiu, A.C. (2020). Lipid Rafts and DA Receptor Signaling. International journal of molecular sciences. 21(23), 8909. Doi: $10.3390 /$ ijms 21238909 .

Miguelez, C., De Deurwaerdère, P. \& Sgambato, V. (2020). Editorial: Non-DArgic Systems in Parkinson's Disease. Frontiers in pharmacology, $11,593822$. Doi: 10.3389/fphar.2020.593822.

Miodownik, C., Lerner, V., Kudkaeva, N., Lerner, P. P., Pashinian, A., Bersudsky, Y., Eliyahu, R., Kreinin, A. \& Bergman, J. (2019). Curcumin as Add-On to Antipsychotic Treatment in Patients with Chronic Schizophrenia: A Randomized, Double-Blind, Placebo-Controlled Study. Clinical Neuropharmacology. 42(4), 117-122. Doi: 10.1097/WNF.0000000000000344.

Mishra, A., Singh, S. \& Shukla, S. (2018). Physiological and Functional Basis of Dopamine Receptors and Their Role in Neurogenesis: Possible Implication for Parkinson's disease. Journal of experimental neuroscience, 12, 1179069518779829. Doi: 10.1177/1179069518779829.

Missale, C., Nash, S.R., Robinson, S.W., Jaber, M. \& Caron., M.G. (1998). DA receptors: from structure to function. Physiol Rev. 78(1), 189-225. Doi: 10.1152/physrev.1998.78.1.189.

Miyoshi, E., Wietzikoski, S., Camplessei, M., Silveira, R., Takahashi, R. N. \& Da Cunha, C. (2002). Impaired learning in a spatial working memory version and in a cued version of the water maze in rats with MPTP-induced mesencephalic DArgic lesions. Brain research bulletin. 58(1), 41-7. Doi: 10.1016/s03619230(02)00754-2. 
Moncrieff, J., Gupta, S. \& Horowitz, M. A. (2020). Barriers to stopping neuroleptic (antipsychotic) treatment in people with schizophrenia, psychosis or bipolar disorder. Therapeutic advances in psychopharmacology. 10, 2045125320937910. Doi: 10.1177/2045125320937910.

Morris, G. M., Huey, R., Lindstrom. W., Sanner, M. F., Belew, R. K., Goodsell, D. S. \& Olson, A. J. (2009). AutoDock4 and AutoDockTools4: Automated docking with selective receptor flexibility. Journal of Computational Chemistry. 30(16), 2785-91. Doi: 10.1002/jcc.21256.

Mrzljak, L., Bergson, C., Pappy, M., Huff, R., Levenson, R. \& Goldman- Rakic, P.S. (1996). Localization of dopamine D4 receptors in GABAergic neurons of the primate brain. Nature. 381, 245-248. Doi: 10.1038/381245a0.

Muhammad, A., Muhammad, J., Farhat, U., Fazal, S., Abdul, S., Gowhar, A., Muhammad, O., Muhammad, S., Ashfaq, A., Abdul, W., Mohamed, E. S., Nisar, A. \& Sajjad, A. (2017). Anti-Alzheimer's Studies on $\beta$-Sitosterol Isolated from Polygonum hydropiper L. Frontiers in Pharmacology. 8, 697. Doi: 10.3389/fphar.2017.00697.

Mythri, R. B. \& Bharath, M.M. (2012). Curcumin: a potential neuroprotective agent in Parkinson's disease. Current Pharmaceutical Design. 18(1), 91-9. Doi: $10.2174 / 138161212798918995$

Nakamura, K., Sekine, Y., Ouchi, Y., Tsujii, M., Yoshikawa, E., Futatsubashi, M., Tsuchiya, K. J., Sugihara, G., Iwata, Y., Suzuki, K., Matsuzaki, H., Suda, S., Sugiyama, T., Takei, N. \& Mori, N. (2010). Brain serotonin and DA transporter bindings in adults with high-functioning autism. Archives Of General Psychiatry. 67, 59-68. Doi: 10.1001/archgenpsychiatry.2009.137.

Neve, K. A., Seamans, J. K. \& Trantham-Davidson, H. (2004). Dopamine receptor signaling. Journal of receptor and signal transduction research. 24(3), 165-205. Doi: 10.1081/rrs-200029981.

Pan, X., Kaminga, A. C., Wen, S. W., Wu, X., Acheampong, K. \& Liu, A. (2019). DA and DA receptors in Alzheimer's Disease: a systematic review and network meta-analysis. Frontiers in Aging Neuroscience. 11, 175. Doi: 10.3389/fnagi.2019.00175.

Park, S.J., Kim, D. H., Jung, J.M., Kim, J.M., Cai, M., Liu, X., Hong, J. G., Lee, C. H., Lee, K. R. \& Ryu, J. H. (2012). The ameliorating effects of stigmasterol on scopolamine-induced memory impairments in mice. European Journal of Pharmacology. 676 (1-3), 64-70. Doi: 10.1016/j.ejphar.2011.11.050

Paus, S., Brecht, H. M., Ko ster, J., Seeger, G., Klockgether, T., \& Wu'llner, U. (2003). Sleep attacks, daytime sleepiness, and DA agonists in Parkinson's disease. Movement Disorders. 18(6), 659-667. Doi: 10.1002/mds.10417.

Pereira, A. S., Shitsuka, D. M., Pereira, F. J. \& Shitsuka, R. (2018) Metodologia do trabalho científico. Santa Maria: UAB / NTE / UFSM.

Peschanski, M., Defer, G., N'guyen, J., Ricolfi, F., Monfort, J., Remy, P., Geny, C., Samson, Y., Hantraye, P., Jeny, R., Gaston, A., Kéravel, Y., Degos, J. D. \& Cesaro, P. (1994). Bilateral motor improvement and alteration of L-dopa effect in two patients with Parkinson's disease following intrastriatal transplantation of foetal ventral mesencephalon. Brain. 117(3), 487-499. Doi: 10.1093/brain/117.3.487.

Raghu, G., Karunanithi, A., Kannan, I. \& Preetha, L., K. (2018). Molecular docking study on curcumin and its derivatives as inhibitors of BACE1 in the treatment of Alzheimer's disease. National Journal of Physiology, Pharmacy and Pharmacology. 8(2), 244-250. Doi:10.5455/njppp.2017.7.1038623102017.

Reichmann, H. (2016). Modern treatment in Parkinson's disease, a personal approach. Journal of neural transmission. 123(1), 73-80. Doi: 10.1007/s00702015-1441-1.

Shruthy, V. S. \& Shakkeela, Y. (2014). In silico design, docking, synthesis, and evaluation of thiazole Schiff bases. International Journal of Pharmacy and Pharmaceutical Sciences. 6(3), 271-5

Steeves, T. D., Ko, J. H., Kideckel, D. M., Rusjan, P., Houle, S., Sandor, P., et al. (2010). Extrastriatal dopaminergic dysfunction in tourette syndrome. Annals of Neurology. 67 (2), 170-181. Doi: 10.1002/ana.21809.

Sterling, T. \& Irwin, J. J. (2015). ZINC 15 - Ligand Discovery for Everyone. Journal of Chemical Information and Modeling. 55(11), 2324-2337. Doi: $10.1021 /$ acs.jcim.5b00559.

Surmeier, D. J., Ding, J., Day, M., Wang, Z. \& Shen, W. (2007). D1 and D2 dopamine-receptor modulation of striatal glutamatergic signaling in striatal medium spiny neurons. Trends in Neuroscience. 30, 228-235. Doi: 10.1016/j.tins.2007.03.008.

Tarazi, F. I., Zhang, K. \& Baldessarini, R. J. (2004). Dopamine D4 receptors: beyond schizophrenia. Journal of receptor and signal transduction research. 24, 131-147. Doi: 10.1081/rrs-200032076.

Thomsen, R. \& Christensen, M. H. (2006). MolDock: A New Technique for High-Accuracy Molecular Docking. Journal of Medicinal Chemistry. 49 (11), 3315-3321. Doi: 10.1021/jm051197e.

Trott, O. \& Olson, A. J. (2010). AutoDock Vina: improving the speed and accuracy of docking with a new scoring function, efficient optimization, and multithreading. Journal of computational chemistry, 31(2), 455-461. Doi: 10.1002/jcc.21334.

Vivancos, M. \& Moreno, J. J. (2005). beta-Sitosterol modulates antioxidant enzyme response in RAW 264.7 macrophages. Free radical biology \& medicine. 39(1), 91-7. Doi: 10.1016/j.freeradbiomed.2005.02.025.

Wang, X, Kim, J. R., Lee, S. B., Kim, Y. J., Jung, M. Y., Kwon, H. W. \& Ahn, Y. J. (2014). Effects of curcuminoids identified in rhizomes of Curcuma longa on BACE-1 inhibitory and behavioral activity and lifespan of Alzheimer's disease Drosophila models. BMC Complementary and Alternative Medicine. 5(14), 88. Doi: 10.1186/1472-6882-14-88.

Wietzikoski, E. C., Boschen, S. L., Miyoshi, E., Bortolanza, M., Dos Santos, L. M., Frank, M., Brandão, M. L., Winn, P. \& Da Cunha, C. (2012). Roles of D1like DA receptors in the nucleus accumbens and dorsolateral striatum in conditioned avoidance responses. Psychopharmacology (Berl). 219(1), 159-69. Doi: $10.1007 / \mathrm{s} 00213-011-2384-3$. 
Wooten, D., Goer, F., Beltzer, M., Vitaliano, G., Brennan, B., Crowley, D., Alpert, N., Normandin, M., Fakhri, G.E. \& Pizzagalli, D. (2015). Reduced striatal DA transporter binding in major depressive disorder. Journal of Nuclear Medicine. 56(3), 527.

Yadav, M., Parle, M., Jindal, D. K. \& Dhingra, S. (2018). Protective effects of stigmasterol against ketamine-induced psychotic symptoms: Possible behavioral, biochemical and histopathological changes in mice. Pharmacological Reports. 70(3), 591-599. Doi: 10.1016/j.pharep.2018.01.001.

Yang, A. C. \& Tsai, S. J. (2017). New Targets for Schizophrenia Treatment beyond the DA Hypothesis. International journal of molecular sciences. 18 , 1689. Doi: 10.3390/ijms18081689.

Yang, P., Perlmutter, J. S., Benzinger, T.L.S., Morris, J. C. \& Xu, J. (2020). Dopamine D3 receptor: A neglected participant in Parkinson Disease pathogenesis and treatment? Ageing Research Reviews. 57, 100994, Doi: 10.1016/j.arr.2019.100994.

Yatham, L. N., Liddle, P. F., Shiah, I.S., Lam, R.W., Ngan, E., Scarrow, G., Imperial, M., Stoessl, J., Sossi, V. \& Ruth, T. J. (2002). PET study of [18F]6fluoro-L-dopa uptake in neuroleptic and mood-stabilizer-naive first-episode nonpsychotic mania: effects of treatment with divalproex sodium. The American Psychiatric Association. 159, 768-774. Doi: 10.1176/appi.ajp.159.5.768.

Yin, Y., Liu, X., Liu, J., Cai, E., Zhao, Y., Li, H., Zhang, L., Li, P. \& Gao, Y. (2018). The effect of beta-sitosterol and its derivatives on depression by the modification of 5-HT, DA and GABA-ergic systems in mice. RSC Advances. 8, 671-680. Doi: 10.1039/C7RA11364A.

Youdim, M., B. H. \& Buccafusco, J. J. (2005). Multi-functional drugs for various CNS targets in the treatment of neurodegenerative disorders. Trends in Pharmacological Sciences. 26(1). Doi: 10.1016/j.tips.2004.11.007.

Yu, Z. F., Kong, L. D. \& Chen, Y. (2002). Antidepressant activity of aqueous extracts of Curcuma longa in mice. Journal of Ethnopharmacology. v. 83. p. 161-165. Doi: 10.1016/S0378-8741(02)00211-8.

Yun, J. Y., Kim, Y. E., Yang, H. J., Kim, H. J. \& Jeon, B. (2017). Twice-Daily versus Once-Daily Pramipexole Extended Release Dosage Regimens in Parkinson's Disease. Parkinson's Disease. 2017, 8518929. Doi: 10.1155/2017/8518929.

Zhai, S., Shen, W., Graves, S. M. \& Surmeier, D. J. (2019). Dopaminergic modulation of striatal function and Parkinson's disease. Journal of neural transmission. 126(4), 411-422. Doi: 10.1007/s00702-019-01997-y.

\section{Supplementary Tables}

Table S1. Virtual screening of secondary metabolites isolated from Curcuma longa L. at the D2 receptor (RMSD Å). Values expressed as mean \pm S.D.M. for four repetitions.

\begin{tabular}{llccc}
\hline & PubChem CID & Autodock-v4.2.3 & Autodock Vina & Molegro-v6.0 \\
\hline 0 & risperidone & $-13.415 \pm 0.114$ & $-11.800 \pm 0.000$ & $-103.979 \pm 3.695$ \\
1 & 5280794 & $-12.852 \pm 0.275$ & $-8.700 \pm 0.000$ & $-82.399 \pm 1.156$ \\
2 & 222284 & $-12.687 \pm 0.213$ & $-8.875 \pm 0.050$ & $-86.074 \pm 0.647$ \\
3 & 9908107 & $-12.527 \pm 0.076$ & $-8.750 \pm 0.058$ & $-79.940 \pm 1.406$ \\
4 & 22213932 & $-12.448 \pm 0.005$ & $-8.225 \pm 0.050$ & $-82.343 \pm 0.299$ \\
5 & 173058 & $-10.585 \pm 0.034$ & $-9.000 \pm 0.000$ & $-76.482 \pm 0.118$ \\
6 & 163263 & $-10.200 \pm 0.043$ & $-7.600 \pm 0.000$ & $-76.107 \pm 1.733$ \\
7 & 13858190 & $-10.012 \pm 0.073$ & $-7.225 \pm 0.050$ & $-75.137 \pm 2.930$ \\
8 & 72326 & $-9.937 \pm 0.142$ & $-9.100 \pm 0.000$ & $-74.643 \pm 0.000$ \\
9 & 102582 & $-9.707 \pm 0.029$ & $-7.450 \pm 0.058$ & $-69.353 \pm 0.000$ \\
10 & 5281437 & $-9.527 \pm 0.015$ & $-7.100 \pm 0.000$ & $-60.050 \pm 0.003$ \\
11 & 61125 & $-9.483 \pm 0.025$ & $-6.800 \pm 0.000$ & $-57.693 \pm 0.016$ \\
12 & 5366016 & $-9.345 \pm 0.201$ & $-8.575 \pm 0.171$ & $-73.614 \pm 1.151$ \\
13 & 522296 & $-9.228 \pm 0.015$ & $-7.000 \pm 0.000$ & $-60.683 \pm 1.468$ \\
14 & 6431015 & $-9.123 \pm 0.005$ & $-6.925 \pm 0.050$ & $-61.517 \pm 4.580$ \\
15 & 11947764 & $-9.120 \pm 0.020$ & $-6.600 \pm 0.000$ & $-60.054 \pm 1.773$ \\
16 & 91753606 & $-9.002 \pm 0.055$ & $-7.275 \pm 0.050$ & $-59.205 \pm 0.004$ \\
17 & 19725 & $-8.992 \pm 0.015$ & $-6.800 \pm 0.000$ & $-60.444 \pm 0.004$ \\
18 & 5321293 & $-8.958 \pm 0.046$ & $-6.500 \pm 0.000$ & $-64.312 \pm 0.235$ \\
& & & &
\end{tabular}




\begin{tabular}{|c|c|c|c|c|}
\hline 19 & 14632996 & $-8.902 \pm 0.123$ & $-8.125 \pm 0.050$ & $-68.920 \pm 1.892$ \\
\hline 20 & 196216 & $-8.880 \pm 0.041$ & $-7.925 \pm 0.096$ & $-67.508 \pm 1.664$ \\
\hline 21 & 6432447 & $-8.863 \pm 0.013$ & $-5.900 \pm 0.000$ & $-53.450 \pm 0.002$ \\
\hline 22 & 494439 & $-8.860 \pm 0.060$ & $-7.600 \pm 0.000$ & $-65.373 \pm 0.000$ \\
\hline 23 & 11736155 & $-8.852 \pm 0.013$ & $-8.175 \pm 0.050$ & $-66.479 \pm 0.925$ \\
\hline 24 & 65575 & $-8.828 \pm 0.005$ & $-6.600 \pm 0.000$ & $-58.463 \pm 2.551$ \\
\hline 25 & 10583 & $-8.818 \pm 0.005$ & $-6.900 \pm 0.000$ & $-65.537 \pm 0.003$ \\
\hline 26 & 442343 & $-8.815 \pm 0.031$ & $-7.950 \pm 0.058$ & $-70.196 \pm 3.980$ \\
\hline 27 & 6365122 & $-8.803 \pm 0.010$ & $-8.050 \pm 0.100$ & $-71.501 \pm 6.022$ \\
\hline 28 & 12311096 & $-8.730 \pm 0.020$ & $-6.200 \pm 0.000$ & $-57.911 \pm 1.736$ \\
\hline 29 & 78265163 & $-8.730 \pm 0.020$ & $-6.200 \pm 0.000$ & $-57.161 \pm 1.508$ \\
\hline 30 & 6427078 & $-8.710 \pm 0.020$ & $-6.800 \pm 0.000$ & $-60.699 \pm 0.003$ \\
\hline 31 & 12315492 & $-8.695 \pm 0.033$ & $-8.050 \pm 0.058$ & $-70.182 \pm 5.966$ \\
\hline 32 & 13213649 & $-8.678 \pm 0.091$ & $-7.500 \pm 0.000$ & $-68.839 \pm 2.071$ \\
\hline 33 & 521253 & $-8.655 \pm 0.039$ & $-8.075 \pm 0.050$ & $-65.789 \pm 0.636$ \\
\hline 34 & 92776 & $-8.640 \pm 0.067$ & $-8.100 \pm 0.000$ & $-69.850 \pm 5.710$ \\
\hline 35 & 167812 & $-8.630 \pm 0.080$ & $-7.400 \pm 0.000$ & $-59.801 \pm 0.004$ \\
\hline 36 & 6432312 & $-8.617 \pm 0.005$ & $-6.575 \pm 0.050$ & $-60.664 \pm 2.287$ \\
\hline 37 & 5281515 & $-8.598 \pm 0.065$ & $-6.400 \pm 0.000$ & $-57.938 \pm 0.235$ \\
\hline 38 & 5365976 & $-8.595 \pm 0.013$ & $-6.725 \pm 0.126$ & $-65.297 \pm 1.263$ \\
\hline 39 & 6429302 & $-8.578 \pm 0.010$ & $-7.700 \pm 0.000$ & $-61.295 \pm 0.266$ \\
\hline 40 & 6857681 & $-8.570 \pm 0.043$ & $-7.800 \pm 0.000$ & $-62.884 \pm 0.935$ \\
\hline 41 & 91746582 & $-8.557 \pm 0.055$ & $-6.400 \pm 0.000$ & $-58.731 \pm 0.001$ \\
\hline 42 & 12304273 & $-8.543 \pm 0.010$ & $-8.000 \pm 0.000$ & $-71.467 \pm 4.423$ \\
\hline 43 & 72503 & $-8.532 \pm 0.005$ & $-6.600 \pm 0.000$ & $-62.190 \pm 0.002$ \\
\hline 44 & 5352653 & $-8.518 \pm 0.005$ & $-7.350 \pm 0.058$ & $-68.011 \pm 4.752$ \\
\hline 45 & 1268142 & $-8.512 \pm 0.015$ & $-6.975 \pm 0.050$ & $-65.269 \pm 0.003$ \\
\hline 46 & 6436348 & $-8.460 \pm 0.020$ & $-6.100 \pm 0.000$ & $-54.702 \pm 1.933$ \\
\hline 47 & 10104370 & $-8.435 \pm 0.013$ & $-7.900 \pm 0.000$ & $-70.113 \pm 5.956$ \\
\hline 48 & 21576980 & $-8.435 \pm 0.030$ & $-6.000 \pm 0.000$ & $-58.182 \pm 0.638$ \\
\hline 49 & 15601436 & $-8.410 \pm 0.020$ & $-7.100 \pm 0.000$ & $-63.921 \pm 0.004$ \\
\hline 50 & 6429350 & $-8.395 \pm 0.024$ & $-7.100 \pm 0.000$ & $-64.438 \pm 0.001$ \\
\hline 51 & 160512 & $-8.370 \pm 0.008$ & $-8.100 \pm 0.000$ & $-67.701 \pm 2.055$ \\
\hline 52 & 221071 & $-8.360 \pm 0.020$ & $-8.000 \pm 0.000$ & $-61.797 \pm 0.003$ \\
\hline 53 & 5315469 & $-8.350 \pm 0.047$ & $-8.400 \pm 0.000$ & $-69.456 \pm 1.293$ \\
\hline 54 & 5281531 & $-8.348 \pm 0.035$ & $-7.400 \pm 0.000$ & $-65.999 \pm 0.251$ \\
\hline 55 & 14350 & $-8.320 \pm 0.020$ & $-6.800 \pm 0.000$ & $-59.130 \pm 0.004$ \\
\hline 56 & 5367608 & $-8.320 \pm 0.787$ & $-7.200 \pm 0.000$ & $-66.755 \pm 0.002$ \\
\hline 57 & 10955174 & $-8.320 \pm 0.014$ & $-5.800 \pm 0.000$ & $-53.837 \pm 0.001$ \\
\hline 58 & 5365659 & $-8.262 \pm 0.116$ & $-7.175 \pm 0.050$ & $-71.320 \pm 1.550$ \\
\hline
\end{tabular}




\begin{tabular}{|c|c|c|c|c|}
\hline 59 & 5281520 & $-8.252 \pm 0.005$ & $-7.300 \pm 0.000$ & $-59.159 \pm 0.032$ \\
\hline 60 & 534856 & $-8.223 \pm 0.005$ & $-6.000 \pm 0.000$ & $-55.961 \pm 0.004$ \\
\hline 61 & 519545 & $-8.218 \pm 0.005$ & $-6.400 \pm 0.000$ & $-59.089 \pm 0.002$ \\
\hline 62 & 5370837 & $-8.203 \pm 0.013$ & $-7.800 \pm 0.000$ & $-72.030 \pm 4.067$ \\
\hline 63 & 92139 & $-8.197 \pm 0.010$ & $-8.100 \pm 0.000$ & $-71.202 \pm 3.719$ \\
\hline 64 & 5322111 & $-8.183 \pm 0.015$ & $-6.700 \pm 0.000$ & $-59.504 \pm 0.002$ \\
\hline 65 & 519762 & $-8.160 \pm 0.045$ & $-6.400 \pm 0.000$ & $-61.690 \pm 0.002$ \\
\hline 66 & 14014430 & $-8.102 \pm 0.013$ & $-8.000 \pm 0.000$ & $-71.493 \pm 3.572$ \\
\hline 67 & 6440942 & $-8.100 \pm 0.073$ & $-6.250 \pm 0.100$ & $-59.153 \pm 0.254$ \\
\hline 68 & 5367460 & $-8.092 \pm 0.089$ & $-7.125 \pm 0.096$ & $-66.460 \pm 1.791$ \\
\hline 69 & 5281519 & $-7.992 \pm 0.042$ & $-6.700 \pm 0.000$ & $-56.452 \pm 0.752$ \\
\hline 70 & 6466 & $-7.930 \pm 0.320$ & $-7.100 \pm 0.000$ & $-66.159 \pm 0.001$ \\
\hline 71 & 15560276 & $-7.840 \pm 0.000$ & $-7.000 \pm 0.000$ & $-60.206 \pm 0.006$ \\
\hline 72 & 5282184 & $-7.817 \pm 0.063$ & $-6.775 \pm 0.263$ & $-63.914 \pm 3.628$ \\
\hline 73 & 5470187 & $-7.803 \pm 0.005$ & $-6.925 \pm 0.050$ & $-60.705 \pm 0.003$ \\
\hline 74 & 64971 & $-7.797 \pm 0.252$ & $-9.300 \pm 0.000$ & $-74.363 \pm 0.001$ \\
\hline 75 & 445070 & $-7.785 \pm 0.051$ & $-7.225 \pm 0.150$ & $-67.667 \pm 1.094$ \\
\hline 76 & 494329 & $-7.748 \pm 0.005$ & $-7.500 \pm 0.000$ & $-62.089 \pm 0.031$ \\
\hline 77 & 15559499 & $-7.742 \pm 0.005$ & $-6.900 \pm 0.000$ & $-58.696 \pm 2.525$ \\
\hline 78 & 6430550 & $-7.655 \pm 0.044$ & $-6.800 \pm 0.115$ & $-62.962 \pm 2.383$ \\
\hline 79 & 5281517 & $-7.575 \pm 0.066$ & $-7.300 \pm 0.082$ & $-70.236 \pm 7.362$ \\
\hline 80 & 6440940 & $-7.547 \pm 0.041$ & $-6.500 \pm 0.000$ & $-59.310 \pm 0.002$ \\
\hline 81 & 1752 & $-7.543 \pm 0.062$ & $-7.450 \pm 0.058$ & $-69.273 \pm 2.976$ \\
\hline 82 & 92812 & $-7.485 \pm 0.117$ & $-7.100 \pm 0.000$ & $-59.749 \pm 0.002$ \\
\hline 83 & 11996452 & $-7.440 \pm 0.040$ & $-6.900 \pm 0.000$ & $-59.535 \pm 0.002$ \\
\hline 84 & 526687 & $-7.388 \pm 0.055$ & $-7.600 \pm 0.000$ & $-62.280 \pm 0.002$ \\
\hline 85 & 12304985 & $-7.372 \pm 0.010$ & $-6.900 \pm 0.000$ & $-60.927 \pm 0.001$ \\
\hline 86 & 2355 & $-7.348 \pm 0.015$ & $-6.550 \pm 0.058$ & $-56.770 \pm 0.003$ \\
\hline 87 & 66514 & $-7.173 \pm 0.030$ & $-6.825 \pm 0.050$ & $-67.951 \pm 0.022$ \\
\hline 88 & 14109432 & $-7.168 \pm 0.049$ & $-6.000 \pm 0.000$ & $-53.787 \pm 0.186$ \\
\hline 89 & 91354 & $-7.120 \pm 0.000$ & $-7.525 \pm 0.050$ & $-62.498 \pm 0.001$ \\
\hline 90 & 10910653 & $-7.080 \pm 0.020$ & $-7.400 \pm 0.000$ & $-60.735 \pm 0.002$ \\
\hline 91 & 5364174 & $-6.988 \pm 0.162$ & $-7.125 \pm 0.050$ & $-66.183 \pm 0.427$ \\
\hline 92 & 8181 & $-6.973 \pm 0.182$ & $-6.250 \pm 0.129$ & $-62.279 \pm 2.038$ \\
\hline 93 & 460 & $-4.855 \pm 0.006$ & $-5.800 \pm 0.000$ & $-62.156 \pm 0.001$ \\
\hline
\end{tabular}


Table S2. Virtual screening of secondary metabolites isolated from Curcuma longa L. at the D3 receptor (RMSD $\AA$ ). Values expressed as mean \pm S.D.M. for four repetitions.

\begin{tabular}{|c|c|c|c|c|}
\hline & PubChem CID & Autodock-v4.2.3 & Molegro-v6.0 & Autodock Vina \\
\hline 0 & eticlopride & $-9.417 \pm 0.067$ & $-85.143 \pm 0.037$ & $-8.400 \pm 0.000$ \\
\hline 1 & 5280794 & $-13.390 \pm 0.110$ & $-91.968 \pm 0.017$ & $-10.000 \pm 0.000$ \\
\hline 2 & 222284 & $-13.295 \pm 0.142$ & $-96.711 \pm 0.185$ & $-9.325 \pm 0.126$ \\
\hline 3 & 9908107 & $-12.633 \pm 0.022$ & $-91.975 \pm 0.145$ & $-9.575 \pm 0.519$ \\
\hline 4 & 22213932 & $-12.465 \pm 0.013$ & $-92.216 \pm 0.001$ & $-9.350 \pm 0.191$ \\
\hline 5 & 13858190 & $-9.920 \pm 0.059$ & $-75.674 \pm 0.010$ & $-8.125 \pm 0.050$ \\
\hline 6 & 163263 & $-9.420 \pm 0.008$ & $-72.764 \pm 0.003$ & $-7.600 \pm 0.000$ \\
\hline 7 & 173058 & $-9.350 \pm 0.061$ & $-69.112 \pm 0.002$ & $-8.450 \pm 0.058$ \\
\hline 8 & 5367608 & $-8.782 \pm 0.017$ & $-71.859 \pm 0.003$ & $-8.500 \pm 0.000$ \\
\hline 9 & 19725 & $-8.780 \pm 0.000$ & $-70.344 \pm 0.001$ & $-7.400 \pm 0.000$ \\
\hline 10 & 494329 & $-8.738 \pm 0.005$ & $-66.514 \pm 0.000$ & $-8.600 \pm 0.000$ \\
\hline 11 & 5365976 & $-8.630 \pm 0.008$ & $-75.854 \pm 0.094$ & $-7.100 \pm 0.000$ \\
\hline 12 & 526687 & $-8.560 \pm 0.000$ & $-72.213 \pm 0.000$ & $-8.500 \pm 0.000$ \\
\hline 13 & 196216 & $-8.523 \pm 0.022$ & $-78.884 \pm 0.013$ & $-7.000 \pm 0.294$ \\
\hline 14 & 494439 & $-8.510 \pm 0.000$ & $-66.080 \pm 0.003$ & $-7.000 \pm 0.000$ \\
\hline 15 & 91354 & $-8.490 \pm 0.000$ & $-70.445 \pm 0.001$ & $-8.175 \pm 0.050$ \\
\hline 16 & 13213649 & $-8.480 \pm 0.038$ & $-77.324 \pm 0.585$ & $-7.550 \pm 0.100$ \\
\hline 17 & 5470187 & $-8.480 \pm 0.000$ & $-66.310 \pm 0.001$ & $-7.500 \pm 0.000$ \\
\hline 18 & 5352653 & $-8.457 \pm 0.010$ & $-75.730 \pm 0.002$ & $-7.500 \pm 0.000$ \\
\hline 19 & 61125 & $-8.440 \pm 0.000$ & $-60.531 \pm 0.001$ & $-7.700 \pm 0.000$ \\
\hline 20 & 1268142 & $-8.390 \pm 0.012$ & $-65.832 \pm 0.001$ & $-7.425 \pm 0.050$ \\
\hline 21 & 5281437 & $-8.390 \pm 0.000$ & $-63.626 \pm 0.001$ & $-7.400 \pm 0.000$ \\
\hline 22 & 5322111 & $-8.380 \pm 0.000$ & $-69.239 \pm 0.001$ & $-7.100 \pm 0.000$ \\
\hline 23 & 6429302 & $-8.335 \pm 0.010$ & $-76.170 \pm 0.017$ & $-7.300 \pm 0.000$ \\
\hline 24 & 6440942 & $-8.330 \pm 0.008$ & $-67.409 \pm 0.002$ & $-6.800 \pm 0.000$ \\
\hline 25 & 6440940 & $-8.303 \pm 0.017$ & $-65.927 \pm 0.002$ & $-7.000 \pm 0.000$ \\
\hline 26 & 14632996 & $-8.277 \pm 0.026$ & $-75.573 \pm 0.028$ & $-7.100 \pm 0.231$ \\
\hline 27 & 5364174 & $-8.277 \pm 0.005$ & $-71.072 \pm 0.005$ & $-8.600 \pm 0.000$ \\
\hline 28 & 6857681 & $-8.265 \pm 0.070$ & $-78.213 \pm 0.054$ & $-7.300 \pm 0.000$ \\
\hline 29 & 519545 & $-8.250 \pm 0.000$ & $-60.496 \pm 0.001$ & $-7.300 \pm 0.000$ \\
\hline 30 & 12315492 & $-8.242 \pm 0.098$ & $-77.232 \pm 1.035$ & $-7.100 \pm 0.200$ \\
\hline 31 & 10104370 & $-8.240 \pm 0.116$ & $-78.037 \pm 0.375$ & $-6.975 \pm 0.150$ \\
\hline 32 & 91753606 & $-8.240 \pm 0.000$ & $-73.865 \pm 0.000$ & $-7.900 \pm 0.000$ \\
\hline 33 & 5366016 & $-8.223 \pm 0.196$ & $-91.473 \pm 2.217$ & $-7.875 \pm 0.096$ \\
\hline 34 & 21576980 & $-8.200 \pm 0.000$ & $-63.146 \pm 0.001$ & $-6.900 \pm 0.000$ \\
\hline 35 & 6431015 & $-8.190 \pm 0.000$ & $-63.833 \pm 0.001$ & $-7.300 \pm 0.000$ \\
\hline 36 & 521253 & $-8.188 \pm 0.064$ & $-76.842 \pm 0.004$ & $-7.200 \pm 0.000$ \\
\hline 37 & 12304985 & $-8.180 \pm 0.000$ & $-66.230 \pm 0.001$ & $-7.000 \pm 0.000$ \\
\hline
\end{tabular}




\begin{tabular}{|c|c|c|c|}
\hline 38 & 11736155 & $-8.178 \pm 0.028$ & $-75.699 \pm 0.066-7.350 \pm 0.058$ \\
\hline 39 & 6432447 & $-8.170 \pm 0.000$ & $-63.576 \pm 0.001-6.800 \pm 0.000$ \\
\hline 40 & 6365122 & $-8.113 \pm 0.026$ & $-78.455 \pm 0.005-7.600 \pm 0.000$ \\
\hline 4 & 92776 & $-8.092 \pm 0.113$ & $-77.713 \pm 0.021-6.975 \pm 0.126$ \\
\hline & 5281531 & $-8.080 \pm 0.041$ & $-74.384 \pm 0.007-6.900 \pm 0.082$ \\
\hline & 6427078 & $-8.060 \pm 0.000$ & $-58.647 \pm 0.002-7.100 \pm 0.000$ \\
\hline 44 & 15601436 & $-8.053 \pm 0.052$ & $-64.159 \pm 0.001-7.300 \pm 0.000$ \\
\hline 45 & 221071 & $-8.040 \pm 0.000$ & $-63.569 \pm 0.001-7.700 \pm 0.000$ \\
\hline 46 & 6429350 & $-8.022 \pm 0.015$ & $-63.450 \pm 0.003-6.900 \pm 0.000$ \\
\hline 4 & 11947764 & $-8.007 \pm 0.005$ & $-59.970 \pm 0.001-7.200 \pm 0.000$ \\
\hline 48 & 6466 & $-8.005 \pm 0.013$ & $-59.430 \pm 0.001-8.225 \pm 0.150$ \\
\hline 4 & 5281515 & $-8.000 \pm 0.000$ & $-65.167 \pm 0.001-7.100 \pm 0.000$ \\
\hline 50 & 11996452 & $-7.998 \pm 0.005$ & $-61.880 \pm 0.001-7.000 \pm 0.000$ \\
\hline 51 & 160512 & $-7.995 \pm 0.021$ & $-77.025 \pm 0.278-7.400 \pm 0.000$ \\
\hline 52 & 522296 & $-7.990 \pm 0.000$ & $-63.989 \pm 0.001-7.100 \pm 0.000$ \\
\hline 53 & 167812 & $-7.980 \pm 0.000$ & $-67.883 \pm 0.001-7.000 \pm 0.000$ \\
\hline 54 & 92812 & $-7.970 \pm 0.000$ & $-63.494 \pm 0.002-7.100 \pm 0.000$ \\
\hline 55 & 12304273 & $-7.965 \pm 0.064$ & $-77.357 \pm 0.159-7.100 \pm 0.000$ \\
\hline 6 & 5281520 & $-7.940 \pm 0.000$ & $-66.214 \pm 0.000-6.900 \pm 0.000$ \\
\hline 57 & 10910653 & $-7.930 \pm 0.000$ & $-62.856 \pm 0.001-6.700 \pm 0.000$ \\
\hline 58 & 65575 & $-7.925 \pm 0.006$ & $-61.449 \pm 0.001-6.825 \pm 0.050$ \\
\hline 59 & 14350 & $-7.900 \pm 0.000$ & $-64.148 \pm 0.002-7.050 \pm 0.058$ \\
\hline 60 & 5315469 & $-7.885 \pm 0.082$ & $-75.387 \pm 0.038-7.150 \pm 0.100$ \\
\hline 61 & 5281519 & $-7.850 \pm 0.000$ & $-60.464 \pm 0.001-6.700 \pm 0.000$ \\
\hline 62 & 72326 & $-7.845 \pm 0.013$ & $-67.369 \pm 0.003-6.625 \pm 1.242$ \\
\hline 63 & 92139 & $-7.802 \pm 0.039$ & $-76.202 \pm 0.124-7.175 \pm 0.189$ \\
\hline 64 & 5321293 & $-7.795 \pm 0.006$ & $-69.239 \pm 0.020-7.000 \pm 0.000$ \\
\hline 65 & 442343 & $-7.697 \pm 0.080$ & $-72.852 \pm 0.082-7.375 \pm 0.050$ \\
\hline 66 & 72503 & $-7.695 \pm 0.006$ & $-61.449 \pm 0.002-6.700 \pm 0.000$ \\
\hline 67 & 10583 & $-7.683 \pm 0.005$ & $-69.298 \pm 0.004-6.700 \pm 0.000$ \\
\hline 68 & 5367460 & $-7.660 \pm 0.411$ & $-95.294 \pm 2.130-6.875 \pm 0.150$ \\
\hline 69 & 102582 & $-7.652 \pm 0.021$ & $-69.046 \pm 0.020-7.700 \pm 0.000$ \\
\hline 70 & 5370837 & $-7.645 \pm 0.044$ & $-77.026 \pm 0.378-6.975 \pm 0.096$ \\
\hline 71 & 534856 & $-7.630 \pm 0.000$ & $-56.924 \pm 0.001-6.900 \pm 0.000$ \\
\hline 72 & 10955174 & $-7.620 \pm 0.014$ & $-55.620 \pm 0.001-6.700 \pm 0.000$ \\
\hline 73 & 519762 & $-7.607 \pm 0.013$ & $-65.960 \pm 0.001-6.900 \pm 0.000$ \\
\hline 74 & 5365659 & $-7.572 \pm 0.214$ & $-99.910 \pm 0.604-6.750 \pm 0.058$ \\
\hline 7 & 91746582 & $-7.570 \pm 0.000$ & $-56.760 \pm 0.001-7.125 \pm 0.150$ \\
\hline 7 & 12311096 & $-7.535 \pm 0.006$ & $-60.491 \pm 0.003-6.500 \pm 0.000$ \\
\hline & 78265163 & $-7.535 \pm 0.006$ & $-60.490 \pm 0.004-6.500 \pm 0.000$ \\
\hline
\end{tabular}




\begin{tabular}{lllll}
78 & 15559499 & $-7.502 \pm 0.005$ & $-58.956 \pm 0.001$ & $-6.850 \pm 0.058$ \\
79 & 64971 & $-7.485 \pm 0.021$ & $-68.269 \pm 0.001$ & $-6.625 \pm 0.550$ \\
80 & 14014430 & $-7.385 \pm 0.066$ & $-77.131 \pm 0.077-7.075 \pm 0.050$ \\
81 & 6432312 & $-7.325 \pm 0.037$ & $-64.630 \pm 0.001$ & $-6.450 \pm 0.058$ \\
82 & 15560276 & $-7.320 \pm 0.000$ & $-57.703 \pm 0.000$ & $-6.900 \pm 0.000$ \\
83 & 14109432 & $-7.305 \pm 0.006$ & $-54.613 \pm 0.001-7.000 \pm 0.000$ \\
84 & 5281517 & $-7.240 \pm 0.103$ & $-83.292 \pm 0.466-6.675 \pm 0.096$ \\
85 & 5282184 & $-7.213 \pm 0.152$ & $-94.124 \pm 2.684-6.675 \pm 0.096$ \\
86 & 6430550 & $-7.205 \pm 0.073$ & $-81.518 \pm 1.038$ & $-6.350 \pm 0.058$ \\
87 & 1752 & $-7.100 \pm 0.127$ & $-82.516 \pm 0.881-6.550 \pm 0.058$ \\
88 & 445070 & $-7.092 \pm 0.179$ & $-85.743 \pm 0.496$ & $-6.825 \pm 0.096$ \\
89 & 6436348 & $-7.010 \pm 0.000$ & $-55.921 \pm 0.000$ & $-6.875 \pm 0.050$ \\
90 & 2355 & $-6.580 \pm 0.000$ & $-55.602 \pm 0.001$ & $-6.975 \pm 0.050$ \\
91 & 8181 & $-6.385 \pm 0.285$ & $-89.345 \pm 2.220$ & $-5.875 \pm 0.126$ \\
92 & 66514 & $-6.343 \pm 0.036$ & $-73.825 \pm 0.009$ & $-6.275 \pm 0.050$ \\
93 & 460 & $-4.723 \pm 0.015$ & $-53.961 \pm 0.002$ & $-4.975 \pm 0.050$ \\
\hline
\end{tabular}

Table S3. Virtual screening of secondary metabolites isolated from Curcuma longa L. at the D4 receptor (RMSD $\AA$ ). Values expressed as mean \pm S.D.M. for four repetitions.

\begin{tabular}{|c|c|c|c|c|}
\hline & PubChem CID & Autodock-v4.2.3 & Molegro-v6.0 & Autodock Vina \\
\hline 0 & nemonapride & $-11.302 \pm 0.019$ & $-90.119 \pm 0.037$ & $-9.800 \pm 0.000$ \\
\hline 1 & 5280794 & $-12.777 \pm 0.078$ & $-93.388 \pm 1.162$ & $-10.200 \pm 0.000$ \\
\hline 2 & 22213932 & $-12.555 \pm 0.039$ & $-94.345 \pm 0.010$ & $-10.000 \pm 0.000$ \\
\hline 3 & 222284 & $-12.490 \pm 0.141$ & $-92.053 \pm 0.213$ & $-9.680 \pm 0.126$ \\
\hline 4 & 9908107 & $-12.380 \pm 0.048$ & $-85.438 \pm 0.049$ & $-9.480 \pm 0.096$ \\
\hline 5 & 64971 & $-12.087 \pm 0.005$ & $-73.133 \pm 0.002$ & $-7.780 \pm 0.050$ \\
\hline 6 & 72326 & $-11.783 \pm 0.068$ & $-76.399 \pm 0.002$ & $-9.000 \pm 0.000$ \\
\hline 7 & 13858190 & $-9.668 \pm 0.042$ & $-76.155 \pm 0.393$ & $-8.130 \pm 0.050$ \\
\hline 8 & 173058 & $-9.588 \pm 0.029$ & $-70.589 \pm 0.007$ & $-8.800 \pm 0.000$ \\
\hline 9 & 163263 & $-9.527 \pm 0.010$ & $-76.350 \pm 0.010$ & $-7.900 \pm 0.000$ \\
\hline 10 & 494329 & $-9.450 \pm 0.020$ & $-70.861 \pm 0.016$ & $-9.200 \pm 0.000$ \\
\hline 11 & 5367608 & $-9.010 \pm 0.029$ & $-66.392 \pm 0.107$ & $-8.300 \pm 0.000$ \\
\hline 12 & 6432447 & $-8.825 \pm 0.006$ & $-63.830 \pm 0.001$ & $-7.200 \pm 0.000$ \\
\hline 13 & 6466 & $-8.645 \pm 0.019$ & $-70.020 \pm 0.002$ & $-9.030 \pm 0.050$ \\
\hline 14 & 5366016 & $-8.495 \pm 0.199$ & $-91.725 \pm 2.435$ & $-7.930 \pm 0.150$ \\
\hline 15 & 5470187 & $-8.490 \pm 0.000$ & $-61.274 \pm 0.001$ & $-7.380 \pm 0.050$ \\
\hline 16 & 534856 & $-8.490 \pm 0.000$ & $-62.552 \pm 0.001$ & $-7.100 \pm 0.000$ \\
\hline 17 & 494439 & $-8.455 \pm 0.006$ & $-74.611 \pm 0.002$ & $-8.200 \pm 0.000$ \\
\hline 18 & 91354 & $-8.440 \pm 0.000$ & $-72.191 \pm 0.000$ & $-8.400 \pm 0.000$ \\
\hline 19 & 526687 & $-8.430 \pm 0.000$ & $-70.561 \pm 0.001$ & $-8.300 \pm 0.000$ \\
\hline 20 & 102582 & $-8.378 \pm 0.030$ & $-70.059 \pm 0.082$ & $-8.300 \pm 0.000$ \\
\hline
\end{tabular}




\begin{tabular}{|c|c|c|c|c|}
\hline 21 & 5281515 & $-8.350 \pm 0.000$ & $-65.940 \pm 0.001$ & $-8.100 \pm 0.000$ \\
\hline 22 & 5281437 & $-8.330 \pm 0.000$ & $-63.829 \pm 0.006$ & $-8.000 \pm 0.000$ \\
\hline 23 & 6431015 & $-8.320 \pm 0.000$ & $-68.620 \pm 0.002$ & $-8.000 \pm 0.000$ \\
\hline 24 & 19725 & $-8.305 \pm 0.013$ & $-68.874 \pm 0.001$ & $-7.100 \pm 0.000$ \\
\hline 25 & 11947764 & $-8.295 \pm 0.006$ & $-64.166 \pm 0.001$ & $-7.300 \pm 0.000$ \\
\hline 26 & 65575 & $-8.293 \pm 0.005$ & $-60.239 \pm 0.002$ & $-7.600 \pm 0.000$ \\
\hline 27 & 6429350 & $-8.290 \pm 0.041$ & $-72.221 \pm 0.002$ & $-7.630 \pm 0.050$ \\
\hline 28 & 221071 & $-8.290 \pm 0.000$ & $-65.134 \pm 0.002$ & $-8.180 \pm 0.050$ \\
\hline 29 & 522296 & $-8.280 \pm 0.000$ & $-67.087 \pm 0.001$ & $-7.700 \pm 0.000$ \\
\hline 30 & 5322111 & $-8.257 \pm 0.005$ & $-64.876 \pm 0.001$ & $-7.200 \pm 0.000$ \\
\hline 31 & 91753606 & $-8.207 \pm 0.060$ & $-65.539 \pm 0.001$ & $-7.500 \pm 0.000$ \\
\hline 32 & 11996452 & $-8.182 \pm 0.005$ & $-70.436 \pm 0.001$ & $-7.900 \pm 0.000$ \\
\hline 33 & 6427078 & $-8.160 \pm 0.000$ & $-65.349 \pm 0.002$ & $-7.330 \pm 0.050$ \\
\hline 34 & 12304985 & $-8.160 \pm 0.000$ & $-64.420 \pm 0.001$ & $-7.500 \pm 0.000$ \\
\hline 35 & 91746582 & $-8.160 \pm 0.000$ & $-64.826 \pm 0.001$ & $-7.900 \pm 0.000$ \\
\hline 36 & 92812 & $-8.150 \pm 0.000$ & $-67.337 \pm 0.001$ & $-7.700 \pm 0.000$ \\
\hline 37 & 6440942 & $-8.150 \pm 0.000$ & $-66.985 \pm 0.003$ & $-6.700 \pm 0.000$ \\
\hline 38 & 10910653 & $-8.140 \pm 0.000$ & $-68.245 \pm 0.001$ & $-7.500 \pm 0.000$ \\
\hline 39 & 15560276 & $-8.140 \pm 0.000$ & $-66.077 \pm 0.001$ & $-7.400 \pm 0.000$ \\
\hline 40 & 12311096 & $-8.133 \pm 0.112$ & $-57.781 \pm 0.002$ & $-6.700 \pm 0.000$ \\
\hline 41 & 61125 & $-8.090 \pm 0.000$ & $-60.607 \pm 0.002$ & $-7.200 \pm 0.000$ \\
\hline 42 & 78265163 & $-8.085 \pm 0.083$ & $-57.781 \pm 0.002$ & $-6.700 \pm 0.000$ \\
\hline 43 & 15601436 & $-8.080 \pm 0.000$ & $-67.030 \pm 0.004$ & $-7.200 \pm 0.000$ \\
\hline 44 & 14350 & $-8.070 \pm 0.000$ & $-70.316 \pm 0.002$ & $-7.530 \pm 0.050$ \\
\hline 45 & 1268142 & $-8.055 \pm 0.006$ & $-67.577 \pm 0.002$ & $-7.600 \pm 0.000$ \\
\hline 46 & 167812 & $-8.050 \pm 0.000$ & $-62.609 \pm 0.001$ & $-7.800 \pm 0.000$ \\
\hline 47 & 72503 & $-8.047 \pm 0.013$ & $-62.939 \pm 0.004$ & $-7.000 \pm 0.000$ \\
\hline 48 & 5365659 & $-8.030 \pm 0.321$ & $-97.150 \pm 2.938$ & $-7.030 \pm 0.050$ \\
\hline 49 & 6857681 & $-7.960 \pm 0.080$ & $-70.926 \pm 0.743$ & $-6.830 \pm 0.096$ \\
\hline 50 & 14109432 & $-7.958 \pm 0.005$ & $-57.123 \pm 0.001$ & $-6.200 \pm 0.000$ \\
\hline 51 & 6429302 & $-7.947 \pm 0.135$ & $-72.202 \pm 0.010$ & $-6.980 \pm 0.050$ \\
\hline 52 & 5364174 & $-7.947 \pm 0.013$ & $-68.080 \pm 0.128$ & $-8.400 \pm 0.000$ \\
\hline 53 & 5281531 & $-7.940 \pm 0.022$ & $-73.655 \pm 0.054$ & $-6.880 \pm 0.050$ \\
\hline 54 & 519545 & $-7.897 \pm 0.022$ & $-60.860 \pm 0.003$ & $-7.300 \pm 0.000$ \\
\hline 55 & 6440940 & $-7.895 \pm 0.006$ & $-62.125 \pm 0.004$ & $-7.200 \pm 0.200$ \\
\hline 56 & 21576980 & $-7.890 \pm 0.120$ & $-57.999 \pm 0.001$ & $-6.600 \pm 0.000$ \\
\hline 57 & 13213649 & $-7.878 \pm 0.030$ & $-78.236 \pm 1.216$ & $-7.580 \pm 0.050$ \\
\hline 58 & 5281520 & $-7.842 \pm 0.005$ & $-62.109 \pm 0.002$ & $-7.400 \pm 0.000$ \\
\hline 59 & 5365976 & $-7.827 \pm 0.215$ & $-75.414 \pm 0.215$ & $-7.200 \pm 0.000$ \\
\hline 60 & 10955174 & $-7.810 \pm 0.000$ & $-53.005 \pm 0.000$ & $-6.800 \pm 0.00$ \\
\hline
\end{tabular}




\begin{tabular}{|c|c|c|c|c|}
\hline 61 & 519762 & $-7.787 \pm 0.202$ & $-67.816 \pm 0.004$ & $-6.800 \pm 0.000$ \\
\hline 62 & 15559499 & $-7.670 \pm 0.000$ & $-57.660 \pm 0.001$ & $-6.900 \pm 0.000$ \\
\hline 63 & 6436348 & $-7.640 \pm 0.000$ & $-55.393 \pm 0.004$ & $-6.800 \pm 0.000$ \\
\hline 64 & 196216 & $-7.623 \pm 0.255$ & $-72.533 \pm 0.244$ & $-7.300 \pm 0.000$ \\
\hline 65 & 92776 & $-7.618 \pm 0.149$ & $-75.811 \pm 0.506$ & $-6.880 \pm 0.150$ \\
\hline 66 & 12304273 & $-7.548 \pm 0.051$ & $-75.589 \pm 1.204$ & $-7.250 \pm 0.058$ \\
\hline 67 & 11736155 & $-7.535 \pm 0.291$ & $-74.205 \pm 0.573$ & $-7.300 \pm 0.000$ \\
\hline 68 & 5367460 & $-7.532 \pm 0.155$ & $-92.173 \pm 3.264$ & $-6.730 \pm 0.222$ \\
\hline 69 & 5281519 & $-7.530 \pm 0.000$ & $-65.343 \pm 0.001$ & $-6.700 \pm 0.000$ \\
\hline 70 & 14632996 & $-7.510 \pm 0.195$ & $-74.036 \pm 0.221$ & $-7.380 \pm 0.150$ \\
\hline 71 & 6365122 & $-7.498 \pm 0.050$ & $-74.148 \pm 1.818$ & $-7.400 \pm 0.000$ \\
\hline 72 & 6432312 & $-7.492 \pm 0.005$ & $-68.493 \pm 0.000$ & $-7.000 \pm 0.000$ \\
\hline 73 & 5352653 & $-7.467 \pm 0.026$ & $-72.686 \pm 0.074$ & $-6.900 \pm 0.000$ \\
\hline 74 & 5321293 & $-7.450 \pm 0.203$ & $-68.854 \pm 0.013$ & $-6.800 \pm 0.000$ \\
\hline 75 & 521253 & $-7.438 \pm 0.029$ & $-74.116 \pm 0.464$ & $-7.400 \pm 0.000$ \\
\hline 76 & 10583 & $-7.420 \pm 0.008$ & $-69.888 \pm 0.013$ & $-6.800 \pm 0.000$ \\
\hline 77 & 5315469 & $-7.397 \pm 0.170$ & $-77.334 \pm 1.148$ & $-7.250 \pm 0.129$ \\
\hline 78 & 12315492 & $-7.388 \pm 0.099$ & $-75.391 \pm 0.356$ & $-7.080 \pm 0.250$ \\
\hline 79 & 160512 & $-7.345 \pm 0.087$ & $-76.563 \pm 1.127$ & $-7.530 \pm 0.050$ \\
\hline 80 & 92139 & $-7.342 \pm 0.244$ & $-76.282 \pm 0.035$ & $-7.250 \pm 0.100$ \\
\hline 81 & 10104370 & $-7.327 \pm 0.088$ & $-75.869 \pm 0.438$ & $-7.400 \pm 0.000$ \\
\hline 82 & 442343 & $-7.202 \pm 0.053$ & $-78.148 \pm 0.027$ & $-6.800 \pm 0.000$ \\
\hline 83 & 5282184 & $-7.143 \pm 0.196$ & $-92.085 \pm 4.888$ & $-6.350 \pm 0.129$ \\
\hline 84 & 5370837 & $-7.002 \pm 0.189$ & $-78.169 \pm 0.147$ & $-7.180 \pm 0.050$ \\
\hline 85 & 14014430 & $-6.895 \pm 0.084$ & $-76.892 \pm 0.072$ & $-7.180 \pm 0.050$ \\
\hline 86 & 2355 & $-6.788 \pm 0.005$ & $-63.458 \pm 0.003$ & $-7.430 \pm 0.050$ \\
\hline 87 & 1752 & $-6.723 \pm 0.180$ & $-80.090 \pm 0.717$ & $-6.500 \pm 0.141$ \\
\hline 88 & 6430550 & $-6.695 \pm 0.337$ & $-77.300 \pm 1.046$ & $-6.280 \pm 0.189$ \\
\hline 89 & 5281517 & $-6.613 \pm 0.075$ & $-79.940 \pm 1.218$ & $-6.350 \pm 0.173$ \\
\hline 90 & 445070 & $-6.560 \pm 0.125$ & $-79.926 \pm 0.969$ & $-6.700 \pm 0.115$ \\
\hline 91 & 8181 & $-6.085 \pm 0.074$ & $-84.469 \pm 1.915$ & $-5.730 \pm 0.206$ \\
\hline 92 & 66514 & $-5.912 \pm 0.186$ & $-70.527 \pm 1.328$ & $-6.150 \pm 0.058$ \\
\hline 93 & 460 & $-4.558 \pm 0.065$ & $-56.751 \pm 0.002$ & $-5.500 \pm 0.000$ \\
\hline
\end{tabular}

